\title{
1 Effects of solarisation on soil thermal-physical properties under different soil \\ treatments: A review
}

\author{
Ahmed Abed Gatea Al-Shammarya, ${ }^{\mathrm{a}, *}$, Abbas Kouzani ${ }^{\mathrm{a}}$, Yeboah Gyasi-Agyei ${ }^{\mathrm{c}}$, Will Gates ${ }^{\mathrm{d}}$, Jesús \\ Rodrigo-Comino,
}

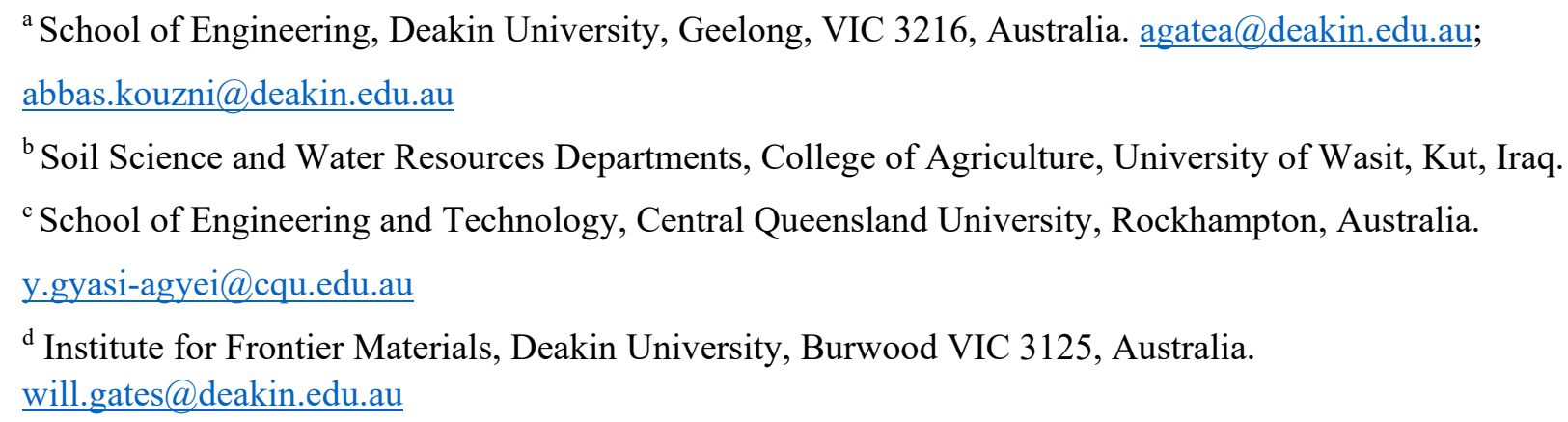

\section{ABSTRACT}

Solarisation technology allows for improving soil quality as well as crop productivity. The influence of the properties and method of use of plastic materials used to cover soils, such as the number and thickness of layers, and colour of the material, significantly alters soil thermal-physical properties. These effects can be managed and modified to increase solarisation efficiency by achieving a decrease in vapour movement between the soil surface and the atmosphere. Also, soil solarisation establishes microclimates that increase the effectiveness of fertilisers, thus modifying the soil thermal-physical properties. However, there is a lack of complete and general overview of this widely used technology. This paper presents a comprehensive review of soil solarisation technology and describes the impacts it has on soil thermal-physical properties when combined with different soil treatments. It is well-known that the efficiency of solarisation technology increases with temperature. However, we describe that the heat 
32 transfer effectivity depends on several different soil thermal-physical properties such as the soil thermal

33 flux, conductivity, diffusivity, soil volumetric heat capacity, and soil temperature. Other soil physical

34 properties such as soil texture, soil bulk density, soil porosity, and soil volumetric moisture content have

35 contributions to make. Moreover, there are several external factors which significantly modify the

36 effectiveness of heat transfer under different solarisation conditions, particularly the weather conditions,

37 the type of tillage management, properties of plastics used and moisture content. We conclude that more

38 research needs to be done: (i) to quantify the degree to which soil thermal-physical properties affect soil

39 solarisation technology, and (ii) to assess the impact of soil technology on crop productivity and quality.

40

41 Keywords: Solarisation technology; soil thermal-physical properties; external factors; tillage management;

42 soil mulches; fertiliser.

43

44

45 


\section{INTRODUCTION}

47

Solar is a cost-effective and eco-friendly energy source in agriculture. Therefore, it is an indispensable source of natural and clean energy for farmers, especially in the underdeveloped and developing regions of the world (Gatea, 2010; Waewsak et al., 2006). Solar energy can also be used to develop other kinds of technologies, such as soil solarisation technology (solar heating). Soil solarisation aims to improve soil properties and controls the soil-borne disease by improving soil water and temperature conservation (Cerdà et al., 2016; da Silva et al., 2018; Kanaan et al., 2018).

By mulching the soil with a polyethene film, which can be transparent or black, solar heating is transferred to the wet soil horizons and strongly alters the solarisation process. This solarisation technology, which can be applied without using chemicals or pesticides, enhances the elimination of soil pathogens. It is one of the best alternatives in terms of environmental sustainability for controlling weeds and pests in high-temperature soils (Carrieri et al., 2013; Katan, 2017; Morra et al., 2018). Soil temperature can reach between $40^{\circ} \mathrm{C}$ and $50^{\circ} \mathrm{C}$ near the soil surface during the day when the soil is covered by plastic mulch during the summer seasons in semi- and arid areas. It is reported to be a key factor for agricultural productivity and soil health (Simmons et al., 2016).

Solarisation of soils is a non-permanent type of soil management as the plastic cover is removed after some weeks. It is used just to enhance: (i) ploughing process; (ii) addition of fertilisers and their mixture into the soil; (iii) maximum irrigation field capacity; and (iv) disinfestation, especially at sites with hot conditions during long summers lasting between 4 and 6 months (Morra et al., 2018; Simmons et al., 2016).

Other benefits of solarisation technology are the modification of the microbial populations, soil functionality, nutrients availability, weed growth and the amount of dissolved organic matter because of its effect on soil temperature (Al-Shammary et al., 2016; Morra et al., 2018). For example, organic matter, soluble forms of nitrogen $\left(\mathrm{NH}_{4+}, \mathrm{NO}_{3^{-}}\right)$and some macro and meso-nutrients $(\mathrm{K}, \mathrm{Mg}, \mathrm{Ca}, \mathrm{Na})$ can increase after applying a solarisation technique (D’Addabbo et al., 2010). Grünzweig et al. (1999) also found that 
71 nitrogen accumulation can increase during soil solarisation because of the higher decomposition rates of

72 the organic matter and the death of microbial biomass. According to Braida et al. (2008), soil organic matter

73 combined with solarisation application can significantly affect soil elasticity which leads to positive effects

74 on soil health by reducing soil compaction, increasing water-holding capacity and heat transfer (Al-

75 Shammary et al., 2017; Chaudhari et al., 2013).

76 Solarisation technology is reported to be effective in increasing soil productivity in many

77 geographical areas (Dai et al., 2014). However, in agricultural ecosystems, it has been noted that

78 solarisation technology has some technical limitations due to some inevitable impacts on soil properties

79 and climatic differences (Katan, 2017; Morra et al., 2018). Over the past two decades, soil mulching using

80 plastic films has improved soil solarisation technology due to a reduction in evaporation of soil moisture

81 and improved soil physical properties such as soil bulk density, porosity and soil temperature (Castello et

82 al., 2017). However, the intensity of sunlight, which affects soil heating, has a significant influence on the

83 efficiency of solarisation technology. Furthermore, the soil depth, air temperature $(T)$, and moisture content

$84(\mu)$ are also important variables in the performance of the solarisation process (D'Addabbo et al., 2010).

85 Soil solarisation technology significantly influences the establishment of microclimates that lead

86 to an increase in the effectiveness of fertilisers in the soil, a reduction in the amount of irrigation (Jiang et

87 al., 2017; Mahdavi et al., 2017), and an improvement of the physical structure of the soil (Figueiredo et al.,

88 2017). Also, it is often presented as improving soil structure in terms of bulk density $\left(\rho_{b}\right)$, porosity $(\Phi)$ and

89 volumetric moisture content $(\theta)$. As a result of these positive impacts, solar heating could generally

90 improve soil quality.

The type of tillage system, the addition of fertiliser, and the influence on inherent soil properties of

92 the plastic mulch are all technical, or management factors, that significantly impact on soil solarisation (Al-

93 Shammary et al., 2017) and soil thermal-physical properties (Blanco-Canqui and Ruis, 2018; Ozpinar et

94 al., 2018). However, there is a lack of a complete and general review of this widely used technology.

95 Therefore, this paper presents a comprehensive review of the literature on soil solarisation technology and

96 describes the impacts on soil thermal-physical properties when combined with different soil treatments. 
97 Specifically, we assess and clarify: (i) how soil solarisation technology works; (ii) the main factors that affect solarisation technology; (iii) mulching cover material properties; and (iv) positive and negative impacts on crop production, soil properties, and the environment.

To achieve these goals, an extended literature review was conducted in order to cover the most important key questions related to how soil solarisation works, the main factors that affect solarisation technology, and its effects on soil thermal-physical properties. A total of 210 original research articles, 13 reviews, and 5 books or book chapters were found dating from 1977 to 2019 . It is also important to state that the search was performed only for indexed and peer-reviewed manuscripts in English.

\section{DEFINITION OF SOIL SOLARISATION TECHNOLOGY AND ITS}

\section{ADVANTAGES AND DISADVANTAGES}

Soil solarisation can be defined as a technology which allows improving the soil thermal-physical properties and is considered as a non-chemical method (Al-Shammary and Al-Sadoon, 2014) which must be applied before planting (Özy1lmaz, 2019). Solarisation technology has been studied by many researchers under different soil management systems in more than 60 countries (Gamliel and Katan, 2005), particularly in arid and semi-arid climates such as in Israel (Katan et al., 1976), California (Pullman et al., 1979), China (Shi et al., 2018), Egypt (Satour et al., 1988; Satour et al., 1991), Spain (Basallote-Ureba and Melero-Vara, 1993), Australia (Forter and Merriman, 1985), New Zealand (McLean et al., 2001), Turkey (Benlioglu et al., 2002; Özyılmaz, 2019) and Iraq (Al-Shammary and Al-Sadoon, 2014). On the other hand, solarisation can be broadly categorised into different groups depending on the different applications carried out by farmers such as i) using the transparent polyethene sheets or other plastic plastics(Gamliel and Katan, 2005). 
121 through the soil profile with temperatures reaching $55^{\circ} \mathrm{C}$ during some weeks (Merfield, 2019; Morra et al.,

122 2018). However, each specific area can show different thermal responses because of different antecedent

123 soil conditions, moisture content being a key factor. The presence of water increases the thermal

124 conductivity, transfer and heat penetration into the soil and, subsequently, the solarisation efficiency (Al-

125 Shammary and Al-Sadoon, 2014; Gamliel and Katan, 2005). For instance, Costa et al. (2019)indicated that

126 solarisation technology is able to transfer the solar radiation out of the plastic film (e.g. polyethene film) on

127 a previously watered field surface for a period of time of not less than 30 days. These authors recommend

128 that the soil should be subjected to furrow or drip irrigation at a watering rate of not less than $30 \mathrm{~mm} / \mathrm{m}^{2}$

129 for a period of two days prior to the solarisation technology application.

It is important to remark that we were not able to find a long list of publications relating to the perception of the residents that live close to plasticised fields, and the opinion and experience of farmers after several years of application of solarisation technologies. Some studies carried out in China and the USA highlighted that farmers are worried about the water consumption, the elevated costs of the materials, Goldberger et al., 2015; Ingman et al., 2015).

\subsection{Advantages}

Soil solarisation has demonstrated positive impacts on some soil characteristics such as soil porosity and availability of soil moisture content because of the improvement in water use efficiency and the reduction in evaporation (Zribi et al., 2015). Also, soil aggregation improves (Kader et al., 2017), and

141 some authors have even demonstrated that solarisation can cause a decrease in soil bulk density (Chen et 142 al., 2015a; Mulumba and Lal, 2008; Wang et al., 2016b). As a result, there is some improvement in the 143 conservation of the topsoil temperatures, which is directly related to better seed germination and root 144 growth (Zhang et al., 2009). Moreover, solarisation can lead to a reduction in weed and pest pressure 145 (McKenzie et al., 2001) by controlling soil-borne diseases as well as increasing soil biological activity 
(Stapleton, 2000). Greenberger et al. (1987) noted that soil solarisation reduces the number of heat-sensitive SBPs such as Verticillium dahliae, Sclerotium rolfsii and Fusarium. Also, Zhang et al. (2018) confirmed that it can cause a reduction in soil salinity, which is vital for the conservation of agricultural productivity and soil fertility in the medium to long terms (Jordán et al., 2010; Moreno and Moreno, 2008). Another key question is related to the clear reduction of water and soil losses (Steinmetz et al., 2016). From an economic point of view, this technology requires only a one-off payment which is less expensive compared to the periodical chemical soil disinfestation (Gamliel and Katan, 2005). Indirectly, the reduction in the use of chemical products also benefits sustainable land management practice (Kanaan et al., 2018).

\subsection{Disadvantages and issues to be solved}

Logically, soil solarisation technology also has negative impacts to be resolved in agriculture despite the numerous of advantages mentioned above. Some authors confirmed that certain drawbacks are associated with the use of soil technology. The solarisation technology is useful only in certain climatic regions characterised by warm conditions and long summers (Ham et al., 1993; Liebman and Gallandt, 1997). Furthermore, solarisation can only be used once a year in the field (Özyılmaz, 2019), and avoids the lack of a crop for some several weeks when implemented (Gamliel and Katan, 2005). For crops with deep roots or deep soil layers, its effectivity is also reduced if the porosity of the soil is elevated before planting (Díaz-Hernández and Salmerón, 2012). Another disadvantage is that the continuous application of solarisation may generate negative influences on beneficial soil microbial communities because of the modification of soil temperature and moisture (Buyer et al., 2010; Gamliel and Stapleton, 1993; Muñoz et al., 2015; Tu et al., 2006). Some authors observed that negative communities of Bacilli and Gammaproteobacteria can increase, and Actinobacteria, Alphaproteobacteria and Acidobacteria may be reduced (Cohen et al., 2018; Kanaan et al., 2018), thus affecting directly the soil quality (Steinmetz et al., 2016). Recently it has been observed that even mycotoxin concentrations in soil could increase (Sabburg et al., 2015; Simmons et al., 2014), and also cause fungal development (Fenoll et al., 2010). Simmons et al. 
171 (2014) observed that a long duration of application of solarisation could show negative effects on fungal

172 epidemics, and on the diversity and richness of the bacteria. Some plastic mulches used for solarisation

173 are found to lead to greenhouse gas emissions, decreasing organic matter contents due to the shifting of the

174 edaphic biocoenosis such as towards mycotoxigenic fungi (Cuello et al., 2015; Steinmetz et al., 2016),

175 However, it has also been recommended not to use organic amendments to solve this issue because it could

176 lead to a decrease in the soil microbial communities (Gamliel et al., 2000; Kipfer et al., 2010). Some

177 studies also demonstrated that soil mulching can cause soil water repellence (Ahmed et al., 2016),

178 thus adversely affecting soil respiration and microbial dynamics (An et al., 2015). Due to the increase

179 in water retention, the risk of high salinity could appear in some cases (Dong et al., 2008), generating a risk

180 of leaching of nutrients, fertilisers and pesticides (Haraguchi et al., 2004; Kim et al., 2014; Leib et al., 2000)

181 which can be transported by both runoff and sediment losses (Zhang et al., 2013). Finally, some technical

182 problems can also be considered as disadvantages. The main ones are related to the elevated costs of the

183 initial investment including the specialised equipment necessary, ongoing monitoring tasks, and the 184 challenges of the removal and disposal processes which result in plastic waste generation with associated 185 high environmental negative impact (Adhikari et al., 2016; Levitan and Barros, 2003; Malinconico et al., 186 2008; Zhang et al., 2019).

187 188

189

190

191 


\section{SOIL SOLARISATION TECHNOLOGY PRINCIPLES AND} PROCEDURES

The procedure for soil solarisation technology combined with different soil treatments can be outlined as depicted in Figure 1 (Abu-Irmaileh, 1991; Barrera Necha and Bautista-Baños, 2016; Gamliel and Katan, 2005; Katan and DeVay, 1991):

a) The field is cleared of plant waste because the soil field should be disturbed as little as possible after plastic removal to avoid recontamination, and the baseline soil physical and chemical properties are determined. Then, it is necessary to select the best time for starting soil mulching considering the climatic conditions related to air temperature and solar radiation. The use of meteorological data from previous years is highly recommended.

b) The selection of an appropriate soil management system is made, including the determination of the primary and secondary equipment to be used. The selection of the best soil tillage depth is also a requirement because solarisation employs the heat of the soil surface through repeated daily cycles. Applying a soil management system by tilling the deepest layers can default the maximal thermal transfer and compact the soil, thus closing the soil pores.

c) Fertilisers are added to the soil by mixing in using disc harrows.

d) A thermocouple-type $(K)$ thermometer is used at different soil depths under the mulch units to measure soil temperature and the temperature in the gap between the mulch cover and the soil surface.

e) The field is irrigated to its maximum field capacity because the most appropriate soil moisture strongly affects soil thermal conductivity and enables the activation of biological activities.

f) The soil is covered by mulch (e.g. polyethene film). The polyethene film is properly unrolled so that it is perfectly attached to the soil surface (Figure 1) in order to achieve maximum efficiency of the solarisation.

g) Solar radiation, soil and ambient temperatures are measured every hour. 
h) Calculations of soil parameters, such as bulk density, porosity, etc., are conducted after removing the covers from the soil.

i) Finally, the field is ready for seed and seedling sowing.

\section{SOIL THERMAL-PHYSICAL PROPERTIES AFFECTED BY SOLARISATION TECHNOLOGY}

The effects of solarisation technology are reported in combination with several factors including soil tillage system, soil structure, mulching cover material properties, fertilisers, moisture content, soil temperature and climatic conditions as depicted in Figure 2 (Braunack et al., 2015; Jiang et al., 2017; ÖZ, 2018).

\subsection{Soil tillage system}

The tillage system employed is one of the key factors on solarisation technology, especially in dryland agricultural fields, because it affects the soil thermal-physical properties due to the strong effects of moisture content, $\mu$, soil temperature, $T_{s}$, and structure of the soil (soil bulk density $\rho_{b}$, soil porosity $\Phi$ ) as shown in Table 1. The two types of soil management used with solarisation are differentiated in Figure 3 : conservation tillage (no-tillage) and conventional tillage (ploughing). It can be observed that soil solarisation process is affected by tillage systems through the interaction with other biological, physical and chemical properties of the soil. For instance, conventional tillage can show positive influences by enhancing soil thermal efficiency compared with conservation tillage. This is because ploughing leads to changes in the soil structure in the surface layer (Maharjan et al., 2018; Ordóñez et al., 2018) by generating a less dense structure in the surface soil layer, playing an important role in reducing soil $\rho_{b}$ (Downie et al., 2015; Dunbabin et al., 2013) compared to the deeper soil layers (Bottinelli et al., 2017; Licht and Al-Kaisi, 2005). Soil $\Phi$ is also influenced by the tillage system (Figueiredo et al., 2017; Głąb and Kulig, 2008; Pires et al., 2017). On the 
other hand, Copec et al. (2015); Kuzucu and Dökmen (2015) have reported that tillage system can increase $\Phi$ because tillage leads to an increase in stored water by increasing infiltration and reducing evaporation. In contrast, no-tillage has some positive impacts on soil moisture capacity as it reduces evaporation (Lampurlanés et al., 2016; Zhao et al., 2018), and soil aeration, and subsequently improves soil thermal properties (Blanco-Canqui and Ruis, 2018). The tillage system has a significant impact on soil thermal properties in the short term(Al-Shammary et al., 2017; Allmaras et al., 1977) as tillage leads to decreased soil thermal conductivity $(k)$ (Blanco-Canqui and Ruis, 2018), soil thermal flux density ( $q$ h) (Azooz et al., 1997), soil volumetric heat capacity $\left(C_{v}\right)$ and soil thermal diffusivity $(D)$ (Blanco-Canqui and Ruis, 2018). No-tillage has a significant effect on soil temperature $\left(T_{s}\right)$ in the upper $20 \mathrm{~cm}$ of soil during spring, which could be reduced compared to conventional tillage (Blanco-Canqui and Ruis, 2018). Other authors have reported a higher soil temperature during solarisation in rotary ploughing compared to mouldboard ploughing due to the higher bulk density resulting from the former $\left(\rho_{b}\right)$ (Al-Shammary and Al-Sadoon, 2014). According to Dec et al. (2009), tillage systems could improve soil structure stability because it reduces soil compaction, and water movement in the soil, consequently improving the heat flow.

4 Soil solarisation has been shown to improve soil structure because it reduces soil compaction by decreasing soil moisture evaporation (D'Addabbo et al., 2010; Melero-Vara et al., 2007). Other studies report that the depth of the tillage does not make any significant difference to the soil bulk density (Jabro et al., 2016; 257 Karuma et al., 2014), and possibly does not have any influence on the effectivity of solarisation. However, 258 no detailed studies of this assertion have been published to our knowledge. Therefore, more research needs 259 to be carried out in order to clarify the impact of bulk density and depth of tillage on heat transmission into 260 the soil.

\subsection{Mulching properties}

Using an appropriate mulching system, soil temperature can be elevated to levels at which 
et al., 2018; Steinmetz et al., 2016). Figure 4 shows the types of mulching material commonly used to cover the soil (Adhikari et al., 2016; Guo et al., 2016; Kader et al., 2017), namely: (i) inorganic materials such as polyethylene plastic films; (ii) organic materials such as plant products and animal waste; (iii) special inert materials such as gravel and concrete, and (iv) mixed materials including plastic, straw, concrete and gravel.

One of the most important elements in the mulches used in solarisation technology is the inorganic material (polyethene) because of its high heating power transmission (Gill, 2014). In the past, materials such as paraffin have also been used because they are more effective at soil heating and faster at the killing of pathogenic soil fungi (Al-Kayssi and Al-Karaghouli, 2002). Nowadays, it is not used because it has been found to increase the biological degradation of litter and soil organic matter (Sinkevičienè et al., 2009).

There is a general consensus that the optimal materials to be used are plastic covers (Kitiş, 2011). They could be considered as a major factor to help soil quality, improve weed management and control the yield response. Also, some kinds of plastics show some mechanical and spectroradiometric properties that can affect heat flow raised in the soil and during weed control. However, they have a drawback of not being biodegradable, recoverable and reusable (Adhikari et al., 2016). Some authors observed that plastic residues reduce nutrient availability (Ibarra-Jiménez et al., 2011), decrease sowing quality (Chang-Rong et al., 2014), and harm soil structure through reducing some soil physical properties (Gao et al., 2019). Thus, from an ecological point of view, they are not the most sustainable solution. Recent soil heating studies used biodegradable plastic covers such as sprayable porous polymer depending on its natural rubber, EVA-doped cover and polyamide-based cover material (Adhikari et al., 2016; Candido et al., 2011; J. Ruhoff et al., 2014; Yang et al., 2015). They are considered easy to apply, providing a good mechanical range of properties, although they were not so effective at transferring soil heat through the soil in several cases. Logically, materials of plant origin, for example, wood shavings, hull, and straw, that are environmentally friendlier are being used (Flores et al., 2007; Mahrer et al., 1984). Moreover, other authors have confirmed that they have other extra benefits apart from being biodegradable such as minimal water and soil losses, maintaining soil temperature in order to raise harvest production, and conserving soil microbial activity (Prosdocimi et al., 2016). Although organic mulching materials are highly recommended, farmers perceive 
them as not the best. A high number of farmers do not accept the application of organic mulches due to the lack of subsidies, and also consider that the mulch portrays the appearance of the fields as dirty and abandoned areas (Cerdà et al., 2018a; Cerdà et al., 2018b). Furthermore, properties of the mulching cover such as the number of layers, thickness and colour of material strongly affect the efficiency of the solarisation technology due to the increase in humus formation and resultant water holding capacity (Castello et al., 2017; da Silva et al., 2018; Ito et al., 2011; ÖZ, 2018). The covering material requires a specific set of properties, which must be conveniently based on the environmental factors of the location and also be cost-effective (Wang et al., 2015). Applying mixed materials (combinations of organic and inorganic materials) could be considered as one of the best strategies for soil management through the application of solarisation technology (Abouziena, 2015; Dong et al., 2009; Luo et al., 2015). Special inert materials such as gravel mulch also be used to decrease soil surface evaporation, and preserve soil moisture contents to meet the demands of plants, resulting in an increase in crop yield in several reported cases (R. Lemon, 1956; Xie et al., 2006; Yamanaka et al., 2004). However, Yuan et al. (2009) showed that the sizes of the gravel mulches had a significant negative correlation with the evaporation processes.

It has been reported that the mulch type significantly influences soil thermal-physical properties (Table 2) such as soil bulk density $\rho_{b}$ and mechanical perturbations (Al-Shammary and Al-Sadoon, 2014; Nishigaki et al., 2017; Nzeyimana et al., 2017), as a consequence of reducing soil compaction (Kader et al., 2017; Nishigaki et al., 2017). Furthermore, mulching system properties can increase the soil volumetric moisture content $\Theta$ as a result of reduction in soil water evaporation which helps to retain soil water content $(\mu)$ (Al-Shammary et al., 2016), and subsequently reduce the amount of irrigation consumption by an 311 increase in soil hydraulic conductivity (Adekiya et al., 2017). properties has been demonstrated in a study that investigated the positive influence of residual plastic film fragments on soil bulk density $\rho_{b}$, porosity $(\Phi)$ and volumetric moisture content $(\theta)$ under two treatments with and without residual plastic film (Mahdavi et al., 2017). Also, Al-Shammary and Al-Sadoon (2014) proposed that covering the soil surface with plastic mulch improves the soil quality because it prevents 
mechanical perturbations in the topsoil. Moreover, other authors found that plastic mulching significantly reduces the organic content of the soil because it negatively affects microbial dynamics (Cuello et al., 2015). Also, Ham et al. (1993); (Tong et al., 2017) argued that these biological properties are due to the changes in soil thermal conductivity $(k)$, soil thermal flux density $(q h)$, soil volumetric heat capacity $\left(C_{v}\right)$, and soil temperature (Ts), which drastically increase when mulching is applied.

Therefore, we recommend further investigation into the following two vital aspects. Firstly, the effectivity of the different types (materials, colours, and thickness) to improve soil quality in agriculture areas, and, secondly, the perception of farmers. It is clear that the application of any soil remediation technique, nature-based solution or improvement action, would be impossible without understanding the opinion of the stakeholders (Keesstra et al., 2018; Wallace and Jago, 2017). Therefore, each new study should combine consideration of the economic incentives (prices and the ability to be subsidised) and biophysical aspects (soil quality) of plastic mulches.

\subsection{Fertiliser types and additions}

The type of fertiliser applied with solarisation technology can improve soil thermal-physical properties. Table 3 summarises the main results collected from the literature. Currently, there are many types of fertilisers, but organic manure (such as farmyard manure and chicken manure) are mostly used with solarisation technology. This is largely due to the fact that organic manure improves soil properties due to containing nitrogen and phosphate, essential ingredients for soil quality (Haynes and Naidu, 1998).

Soil solarisation technology significantly influences the establishment of microclimates that result in increased fertiliser productivity in the soil (Jiang et al., 2017; Zhou et al., 2017). The influence of organic and chemical fertilisers during the application of soil solarisation technology on soil physical properties has also been investigated. Some authors observed that organic fertiliser significantly decreases the bulk density $\rho_{b}$ by increasing porosity $\Phi$ due to the decrease in soil structural stability (Al-Shammary et al., 2017;

341 Chaudhari et al., 2013; Merante et al., 2017). Fertilisers are also able to increase soil $\Phi$ because they can 
342

343

344

345

346

347

348

349

350

enhance the organic content (Haynes and Naidu, 1998). Moreover, the types of fertilisers used with solarisation technology modify the soil temperature $\left(T_{s}\right)$ and soil thermal-physical properties. For example, research on chemical fertilisers with black plastic mulching indicated the highest soil temperature of $78.3^{\circ} \mathrm{C}$ (time $11 \mathrm{am}$ ) at a soil depth of $10 \mathrm{~cm}$ while the mean ambient temperature and solar radiation were $47^{\circ} \mathrm{C}$ and $1125 \mathrm{w} / \mathrm{m}^{2}$, respectively (Al-Shammary et al., 2016). Jia et al. (2019); (Liu et al., 2018) concluded that the soil $\mathrm{k}, q h, C_{v}$, and $D$ can also increase when fertilisers are applied, possibly because of their positive correlation with organic matter content, the water-holding capacity of the soil and heat transfer. However, no significant differences between fertilisers on soil thermal-physical properties have been demonstrated (Al-Shammary and Al-Sadoon, 2014).

Another area that has not received much attention is the utilisation of solarisation technology in organic farming fields. It would be interesting to contrast the influence of the covers used in fields with and without fertilisers, by considering parameters such as soil quality, productivity and changes in soil properties over medium to long-term periods.

\subsection{Soil moisture content $(\mu)$}

Soil moisture content $(\mu)$ is one of the most significant factors influencing solarisation efficiency, and, therefore, affecting soil thermal-physical properties. The main impacts of soil moisture content are summarised in Table 4. As indicated by some researchers, soil solarisation technology is able to reduce irrigation water consumption (Cerdà et al., 2016; Saglam et al., 2017; Zhou et al., 2017), which is a significant cost saving in semi-arid and arid environments. Moreover, it has been highlighted that the reduction in irrigation water generally results in an improvement of the soil quality (Hayes et al., 2012; Taparauskienė and Miseckaitė, 2014). Furthermore, soil moisture content has a strong relationship with other soil physical properties including bulk density and porosity (Mei-Xian et al., 2013; Teng et al., 2016), and volumetric moisture content (Zhang et al., 2018), which could enhance or degrade the effectiveness of soil infiltration and permeability(Di Prima et al., 2018). Soil moisture content plays a significant role in the soil microbial biomass carbon levels (Smith, 1993) because plastic mulch helps to accelerate 
Carbon/Nitrogen metabolism, which affects both soil organic matter stocks, soil-water repellence and greenhouse gases control (Kader et al., 2017). Soil microbial communities are able to interact among themselves when plastic mulches reach a correct balance of soil moisture content; however, this effectivity will vary depending on the bulk density, porosity and structural stability due to its denser mineral fraction

372 (Guo et al., 2015; Schoenholtz et al., 2000). aggregates, comparing scenarios with and without solarisation technology. This will give insights into the type of material that could be used, and thus save economic resources and minimise water use for irrigation. moisture content as a result of solarisation technology could also affect the thermal flux density $(q h)$, thermal conductivity $(k)$, volumetric heat capacity $\left(C_{v}\right)$, diffusivity $(D)$, and soil temperature $\left(T_{s}\right)$ because the heat flow increases when soil $\mu$ improves (Al-Shammary et al., 2017; Badía et al., 2017; Mengistu et al., 2017). Regardless, there is a lack of information about the possible hygrometrical changes below the cover that would modify the microbiological activity. Thus, urgent research must be carried out to clarify the consequences of solarisation technology on microbiological activity, one of the most important elements in soil health (Rinot et al., 2019).

\subsection{Soil temperature $\left(T_{s}\right)$} solarisation technology results in an increase in efficiency of solarisation and, consequently, thermalphysical changes can be observed. However, this situation can be harmful to live organisms and their activities (Al-Shammary et al., 2016). 
Normally the highest soil temperature with solarisation technology is observed around midday. When the temperature decreases, usually during the night, the effectivity of the solarisation technology at deeper soil depths is drastically decreased (Cohen et al., 2018; Vela et al., 2017; Yao et al., 2016). Several studies have demonstrated a linear increase in all thermal properties with an increase in soil temperature (Lamond and Pielert, 2006; Mengistu et al., 2017; Sun et al., 2016).

Abu-Hamdeh (2003); (Mengistu et al., 2017) found that soil volumetric heat capacity $\left(C_{v}\right)$ is also

affected when $T_{s}$ increases because soil management significantly impacts on soil $\mathrm{C}_{\mathrm{v}}$. thus reducing $\rho_{b}$ and increasing $\Phi$ (Al-Shammary et al., 2017); Sun et al. (2016) argued that soil diffusivity (D) also experience an increase with $T_{s}$.

From a holistic point of view, if soil temperature significantly changes, the soil volumetric heat capacity and diffusivity also change, leading to a reduction in bulk density and an increase in porosity (Barry-Macaulay et al., 2015; Sun et al., 2016). We propose this assumption be tested to support, or otherwise, the possible risks of aggregate stability and soil structure in cultivated soils. have shown a higher effectivity for solarisation technology because of a higher absorption rate of solar radiation to increase soil temperature (Ito et al., 2011; ÖZ, 2018; Tesfaye et al., 2016). However, other groups of researchers contradict this assumption (Al-Shammary et al., 2016; Ibarra-Jiménez et al., 2012). Therefore, if this key question can finally be answered, the definition of the use of a specific colour could 413 help to increase soil biological activity and metabolism (Li et al., 2004; Subrahmaniyan et al., 2006), 414 speeding up the decomposition of organic matter in the soil, which would strongly affect soil thermalphysical properties because of increases in the water-holding capacity (Al-Shammary et al., 2017; Jia et al., 2019; Wang et al., 2016a).

Regardless, a key question could be more related to the colour that is more effective considering the type of crop, weather conditions, soil types, and tillage. Possibly, the debate is more related to the identification of the appropriate cover to use depending on external factors other than colour. 


\subsection{Pedoclimatic factor}

It has been confirmed that there exists a clear relationship between climate and soil type in relation 2015). Climatic conditions affect the level of solar radiation which in turn influences soil temperature, thus,

425 influencing the biological processes(Oberholzer et al., 2017), which can be observed in the short- and 426 medium-terms. Logically, there exists an extremely strong dependence between soil solarisation technology

427 and high levels of solar energy. Therefore, it is important to identify areas where solarisation technologies will be installed given the new trends of temperatures over the world due to climate change. Climate change is resulting in increased duration of the drying periods and elevated temperatures during the non-common seasons(Davidson and Janssens, 2006; Odó Camps and Concepción Ramos, 2011).

Ben-Yephet et al. (1988) demonstrated in a pioneer study that the success of soil solarisation technology is significantly influenced by the intensity and length of sunlight exposure. Other authors have also insisted upon the influence of the location of soil solarisation technology use (Sosnowski et al., 2009). Some studies have demonstrated that the average ambient temperature in glasshouse conditions gradually increases when disinfection starts, but the solarisation efficiency decreases during precipitation and cloudy weather (Dai et al., 2014; Morra et al., 2018). Therefore, soil solarisation technology is widely used in the Mediterranean, deserts and tropical climates that record greater solar radiation levels and higher temperatures, thus increasing solarisation efficiency (Al-Shammary et al., 2016). Dai et al. (2014); Katan and DeVay (1991); (Morra et al., 2018) found that solarisation requires a duration lasting between 40 and 60 days for its influence to reach up to $30 \mathrm{~cm}$ soil depth, a time sufficient to sanitise it. This is because the use of soil solarisation can cause a significant reduction in microbial biomass, enzymatic activities, and weed population including Cyperus rotundus in the short-term (S. F. Ricci et al., 1999). and texture playing key roles (Adekiya et al., 2017; Dong et al., 2018; Pituello et al., 2016). For example, 
dark coloured soils absorb more solar energy compared to lighter coloured soils, thus increasing their soil temperature $\left(T_{s}\right)$ (Stapleton et al., 2000). We emphasise the importance of pedoclimatic surveys (Dagois et al., 2017; Oberholzer et al., 2017), considering soil formation and evolution under different climatic conditions, or stationary situations, in order to shed light on when the stakeholders should use solarisation technology.

\section{IMPACT OF SOLARISATION ON SOIL THERMAL-PHYSICAL}

\section{PROPERTIES}

Soil solarisation technology practices in experimental agriculture have several advantages, including conservation and improvement of soil properties. There have been several longitudinal studies investigating the effects of soil solarisation under different soil treatments. Two types of soil properties, which are significantly affected by soil solarisation technology, are the physical and thermal properties.

\subsection{Soil physical properties}

The improvement of soil physical properties using solarisation technology combined with different soil treatments is one of the major challenges today (Tables 1-5). In this section, we present specific impacts of solarisation technology on some physical properties as indicated in the literature.

\subsubsection{Soil bulk density $\left(\rho_{b}\right)$}

Soil $\rho_{b}$ influences solarisation technology through the solarisation management process, such as tillage system, plastic cover type, and fertiliser or additive type, as well as moisture content and soil temperature (Mondal et al., 2016). It has been demonstrated that the no-tillage system results in an increase in soil $\rho_{b}$ due to the increase in soil compaction (Downie et al., 2015; Muñoz-Romero et al., 2010). A 
relationship between soil tillage management and hydrothermal properties has been reported to influence soil $\rho_{b}$ (Williams et al., 2016).

Huo et al. (2017) studied the combined plastic mulching with buried straw layer on soil organic carbon fractions in a saline arid soil in Northwest China. They used the following treatments: (i) deep

471 ploughing with no plastic film mulching; (ii) deep ploughing with plastic film mulching; (iii) buried maize

472 straw layer with no mulching; and (iv) buried maize straw layer plus plastic film mulching. Their results

473 showed that plastic film mulching increased soil moisture and temperature but reduced soil compaction.

474 This is large because, by reducing evaporation of soil moisture, plastic covering prevents mechanical 475 perturbations in the topsoil which reduces compaction. soil mulching systems have a significant effect on $\rho_{b}$ due to a decrease in soil moisture evaporation (AlShammary and Al-Sadoon, 2014). On the other hand, no-covering resulted in an increase in soil $\rho_{b}$ under conventional tillage such as mouldboard, disc, and rotary ploughing. Other studies performed in Turkey, the United States, and China suggested that organic fertiliser with solarisation technology can improve the physical properties of soils, having a positive effect on $\rho_{b}$ by improving soil biological fertility (Celik et al., 2010; Mitchell et al., 2017; Zhang et al., 2017).

\subsubsection{Soil porosity $(\Phi)$}

It is well-known that soil $\Phi$ is influenced by the tillage system employed, and decreases with soil depth (Figueiredo et al., 2017; Głąb and Kulig, 2008; Pires et al., 2017). Investigations into the differential impacts of mulch type on soil physical properties concluded that the soil mulch system has a significant effect on $\Phi$ (Sinkevičienè et al., 2009). Furthermore, the results revealed that the improvement of soil physical properties varied across the studied locations and mulch type due to the increase in organic matter which can also improve soil aggregation, thus positively influencing $\Phi$ (Nzeyimana et al., 2017). 


\subsubsection{Volumetric moisture content $(\theta)$}

The influence of solarisation technology on $\theta$ is also dependent on the soil tillage method, covering properties (i.e., type of mulching cover material and thickness), fertiliser type, moisture content, and pedoclimatic factors (Kader et al., 2017). Covering the soil affects soil moisture content by reducing the evaporation rate (Mutetwa and Mtaita, 2014).

On the other hand, some studies have proposed that soil solarisation technology is useful for reducing soil moisture losses by conserving water and increasing water use efficiency (Anikwe et al., 2007; Jiang et al., 2017; Lal Bhardwaj, 2013). Particularly, the use of plastic film decreases the amount of water loss caused by evaporation (Al-Shammary et al., 2017; Jiang et al., 2017; Ogundare et al., 2015). Moreover, the number of layers covering the soil has been surveyed and its effect on $\theta$ compared to soil without covering has been reported. The double plastic covering had a higher $\theta$ for soil compared to soils without mulching because of reduction in evaporation (Al-Shammary et al., 2017). Ogundare et al. (2015) compared plastic and organic treatments with control plots and solarisation technology and observed the effects on soil $\theta$. They indicated that plastic covered soil obtained the highest value of soil $\theta$ compared to other soil treatments. Also, the colour of the cover material has been a determinant factor. The transparent plastic covering is reported to retain the greatest amount of moisture compared to black or blue plastic covering at $10 \mathrm{~cm}$ soil depth (Ashrafuzzaman et al., 2011).

\subsection{Soil thermal characteristics}

Soil thermal characteristics are dynamic as they are dependent on the effects of external factors and soil physical characteristics such as tillage depth, bulk density, and moisture content, as well as the current soil field conditions (Wilhelm and Bockheim, 2016; Xiukang et al., 2015; Zhang et al., 2018). However, reports in the literature on soil thermal characteristics are limited (Blanco-Canqui and Ruis, 2018). Mengistu et al. (2017) stated that the soil thermal characteristics are determined by the soil structure, particle size distribution, bulk density $\left(\rho_{b}\right)$, moisture content $(\mu)$, and soil temperature $(T s)$. It is observed that factors 
517 affecting solarisation technology can play an important role in the management practices of soil thermal 518 properties. Therefore, it is important to determine how the soil tillage system, structure, mulching 519 properties, fertiliser, moisture content, soil temperature, and climatic conditions affect and control the transfer of heat in field conditions (Pramanik et al., 2015). Regardless, there has been an increasing amount

521 of literature describing soil thermal characteristics under different conditions, because the investigation into

522 soil thermal characteristics is needed to accurately predict soil temperature (Hu et al., 2016).

523 Furthermore, solar heating integrates soft plants and animal material into the soil, which is mulched under 524 a clear plastic cover. However, some reports propose that there are no significant differences in soil 525 temperature $\left(T_{s}\right)$ paralleled with the solarisation technology process, with black plastic showing the highest temperature due to good light absorption compared to other colours (Oz et al., 2017).

\subsubsection{Soil thermal conductivity $(k ; W / m k)$}

Soil $k$ plays a significant role in calculating heat transfer at the soil surface under ambient conditions and is influenced by geotechnical properties such as mineralogical composition, temperature, dry density, moisture content (Bi et al., 2018; Chen et al., 2015b; Yun and Santamarina, 2008).

No-tillage management can increase soil $k$ by increasing soil moisture content $\mu$ and has a better exchange of energy compared to the soil under conventional tillage due to an increase in heat transfer (Blanco-Canqui and Ruis, 2018). Furthermore, a significant difference between tillage depth with solarisation on soil $k$ has been reported (Al-Shammary and Al-Sadoon, 2014). In this case, $k$ increases with increasing soil depth due to the loosened soil as a result of the tillage process, thus increasing the gas exchange between ambient and soil pores. Soil $k$ depends on bulk density $\left(\rho_{b}\right)$, porosity $(\Phi)$, and volumetric moisture content $(\theta)$ due to the heat transfer in the soil being dependent on the solid phase and mineral composition of the soil (Łydżba et al., 2017; Tokoro et al., 2016). Soil $k$ is strongly impacted by $\mu$ due to their logarithmic relationship, improving the heat flow and enhancing the soil $k$. Furthermore, $k$ increases with soil depth due to the increase in soil $\rho_{b}$ (Abu-Hamdeh, 2000; Merante et al., 2017). The differential 
impact of soil $\Phi$ and $\theta$ on soil $k$ has been investigated and a relationship found between $k, \Phi$ and $\theta$ (Alrtimi et al., 2016). Soil $\rho_{b}$ has an increasing relationship with $k$. The plastic covering influences $k$ by decreasing evaporation (Al-Shammary et al., 2017). Soil $k$ has a direct relationship with $\theta$ under mulching conditions by reducing moisture lost (Al-Shammary and Al-Sadoon, 2014; Azooz et al., 1997; Usowicz et al., 2017). Also, organic matter content has a positive significant influence on soil $k$, both increasing with one another (Jia et al., 2019; Liu et al., 2018; Usowicz et al., 2016). Soil $k$ is influenced by soil temperature in most soil types due to the changes in heat flow in the soil which can influence the movement of moisture, increasing soil temperature $\left(T_{s}\right)$ with solarisation technology, resulting in a change in water state (Al-Shammary and Al-Sadoon, 2014; Lamond and Pielert, 2006; Usowicz et al., 2017).

\subsubsection{Soil volumetric heat capacity $\left(C_{v}, J / m^{3} k\right)$}

Soil $C_{v}$ can be defined as the amount of heat required to increase the temperature of a unit volume of soil by $1^{\circ} \mathrm{K}$ (Hillel, 2003), and it depends on $\theta$ and $\rho_{b}$ (Evett et al., 2012). Soil tillage systems, soil structure, mulching material properties, fertiliser, $\mu$, and $T_{s}$ are all related to $\theta$ and $\rho_{b}$ and have significant effects on the $C_{v}$ of a soil. There are several reports in the literature that determine soil $C_{v}$ under different soil treatments (Al-Shammary and Al-Sadoon, 2014; Levy and Schmidt, 2016; Usowicz et al., 2017). Also, soil $C_{v}$ is strongly influenced by $\mu$ and soil depth (O'Kelly and Sivakumar, 2014). For example, the soil thermal properties of the Antarctic regions have been studied, and it was found that soil $C_{v}$ is dependent on $\mu$ and $\rho_{b}$, and increases with soil depth. Furthermore, $C_{v}$ increases with increasing $\rho_{b}$ and $\mu$ (Levy and Schmidt, 2016). There is very little knowledge about soil $C_{v}$ within tillage systems and the addition of fertiliser. However, the tillage system has greater impacts on soil $C_{v}$ as it is directly related to $\rho_{b}$ (AlShammary and Al-Sadoon, 2014; Evett et al., 2012).

The effect of the cover properties on soil $C_{v}$ has been investigated and the results suggest significant differences between the number of plastic covering layers of the soil. A double layer covering has the highest value $C_{v}$ when compared to single or none due to increased storage of heat in the soil (Al-Shammary 
571

572

573

and Al-Sadoon, 2014). Numerous studies have proposed that soil $C_{v}$ increases linearly with $\mu$ due to the absorption of solar radiation that increases the moisture content $\mu$ (Al-Kayssi et al., 1990; Liu et al., 2008; Łydżba et al., 2017). The application of organic fertiliser can significantly alter the organic content of a soil within a short period, and, when combined with solarisation technology, can result in significant changes in the soil's thermal properties due to the soil $\rho_{b}$ decreasing and $\theta$ increasing, consequently impacting on $C_{v}$ (Dec et al., 2009).

\subsubsection{Soil thermal diffusivity $\left(D ; \mathrm{m}^{2} / \mathrm{sec}\right)$}

Soil $D$ is defined as the ratio of thermal conductivity $(k)$ to the volumetric heat capacity $\left(C_{v}\right)$ of soil (Arkhangelskaya and Lukyashchenko, 2018). Soil tillage systems, soil structure, mulching material properties, the addition of fertiliser, $\mu$, and $T_{c}$ of soil are related to $k$ and $C_{v}$ with significant impacts on the soil D (Al-Shammary and Al-Sadoon, 2014; Blanco-Canqui and Ruis, 2018). The effect of soil heating under tillage and addition of fertiliser on soil $D$ has been previously reported. When the number of fertiliser increases, there is a decrease in the structural stability by increasing organic content with a denser mineral fraction of the soil, which can decrease soil D (Al-Shammary et al., 2017; Blanco-Canqui and Ruis, 2018; Gnatowski, 2009; Hu et al., 2016). Tillage can indirectly decrease soil $D$ by increasing the moisture content of the soil. Soil $\mathcal{D}$ is dependent on $\rho_{b}$ and $\theta$, which have a significant effect on $k$ and $C_{v}$ (Blanco-Canqui and Ruis, 2018).

However, other studies report that soil $D$ is a fundamental property for investigating the thermal process of a soil which depends on $\mu$ and $\theta$ (Arkhangelskaya and Lukyashchenko, 2018; Gnatowski, 2009; Usowicz et al., 2017). Soil $D$ is amplified by increasing $\rho_{b}$ and $\mu$ through improving heat transfer (Miyajima et al., 2015; O'Kelly and Sivakumar, 2014; Usowicz et al., 2016). However, soil $\mathcal{D}$ is decreased by increasing soil $\mu$ (Makarychev and Bolotov, 2017) and increases with soil depth (Levy and Schmidt, 2016). Therefore, it can be deduced that solarisation technology can provide a positive influence on soil $\mathcal{D}$ and soil evaporation (Jabran et al., 2016; Liang et al., 2017). As a result, soil mulching could be useful in reducing 
592

593

594

595

596

597

soil moisture loss, and thus reducing the temperature of the soil (Pramanik et al., 2015; Usowicz et al., 2013). The pioneering study conducted by Allmaras et al. (1977) reported that fertiliser containing organic matter could increase soil $D$ by increasing $k$ and $C_{v}$ through changes in soil $\rho_{b}$ and $\theta$. However, it is not clear whether it is the case for all the soil types and crops.

\subsubsection{Soil heat flux density $\left(q h ; w / m^{2}\right)$}

Soil $q h$ is a single-valued function of $k$ and is related to temperature and soil depth. The $q h$ in a soil is dependent on the amount of energy reaching the surface of the soil and is influenced by climatic conditions, topography, time of day, soil texture, tillage management, mulch system, and application of fertiliser (Al-Shammary and Al-Sadoon, 2014; Usowicz et al., 2017; van Lier and Durigon, 2013). The influence of the depth of a tillage system was reported as significant on soil $q h$ due to the increase in soil temperature near the soil surface by solar radiation (Al-Shammary and Al-Sadoon, 2014). Furthermore, the tillage system decreases soil $k$ by reducing $\rho_{b}$ and increasing $\Phi$ (Azooz et al., 1997; Dec et al., 2009). In this way, plastic mulch could reduce soil temperature and $q$ h due to the plastic covering absorbing solar radiation and reducing heat loss (Abzalov, 2016; Colaizzi et al., 2016). (Nishigaki et al., 2017) demonstrated that, for cultivated soils, covering reduces by more than $49 \%$ of evaporation losses and solar radiation on the soil surface, which is important in estimating the $q h$ between the soil surface and the atmosphere. This is strongly related to the number of plastic layers on the soil (single or double). Layers on the surface produce a relatively large net radiation at the soil surface when using transparent mulches. Water condenses under the transparent plastic covering at night, and the reflected radiation can be absorbed from the soil which protects it from extreme soil temperature increases (Al-Shammary and Al-Sadoon, 2014). 


\section{IMPACT OF SOLARISATION ON PLANT GROWTH AND YIELD}

616

617

618

619

620

621

622

623

624

625

626

627

628

629

630

631

632

633

634

635

636

Previous studies have reported the benefits and limitations of solarisation technologies on plant growth as well as crop yield as shown Fig 5 (Ekebafe et al., 2011; Kasirajan and Ngouajio, 2013; Lobell and Field, 2007). The growth response is increased for plants when solarisation is used, especially in nursery seedlings and deciduous tree crops. Liu et al. (2014a); (Liu et al., 2014b) indicated that solarisation could raise the crop yield by approximately $20-50 \%$ as a result of a decrease in nitrogen leaching, improving soil physical properties such as soil porosity and temperature, and decreasing soil bulk density and water evaporation (Luo et al., 2010; Qin et al., 2013). Furthermore, some authors have demonstrated that the soluble mineral nutrients and mineralised organic matter, which are considered key growth regulation factors, enhance soil biological activities after the application of solarisation, directly affecting crop yield (Chen et al., 1991); Chen and Katan (1980); (Stapleton and E. DeVay, 1984). However, other authors have also stated that soil solarisation shows several limitations on crop production (Bai et al., 2015; ChangRong et al., 2014; Gong et al., 2015; Ibarra-Jiménez et al., 2011; Kim et al., 2014; Liu et al., 2014a) as follow:

- The accumulation of plastic residue in the soil leads to reduced nutrient availability and microbiological activity, which significantly adversely affects crop growth;

- The plastic residue leads to a decrease in sowing quality;

- Plastic mulch wastes lead to reduced soil porosity, thus constraining air circulation, which reduces the activity of the microbial communities, along with water and nutrient penetration speed through the soil profile;

- The root development can be subsequently reduced; and 
- Greenhouse gas emissions can be elevated because changing the strength of the carbon source production sometimes results in lower soil fertility and crop growth.

\section{CONCLUSIONS AND FUTURE RESEARCH}

642 plastic material used to cover the soil, such as the number and thickness of layers and colour of the material 643 that significantly affect soil thermal-physical properties and can increase solarisation efficiency. Other 644 studies have highlighted the combination of the use of fertilisers and solarisation technology and their influence on soil thermal-physical properties due to the establishment of microclimates that increase the effectiveness of fertiliser. In this comprehensive review, we have summarised the literature on soil

647 solarisation technology and described the impacts of the solarisation process on soil thermal-physical properties when combined with different soil treatments.

After performing an exhaustive literature review, we also observed several areas that lack information that must be provided in future research. Some studies have investigated soil physical properties under the application of solarisation technology, particularly the influence of tillage systems, mulching cover material properties, fertiliser type, soil moisture content and soil temperature on soil bulk density, soil porosity, and soil volumetric moisture content under different conditions. It would be interesting to assess the effects of the different soil tillage systems (tillage depths, different ploughs), mulching material properties (thickness, colour, number of layers, etc.), and fertiliser types (cattle waste, 
soil thermal properties. This research has uncovered several clear gaps in knowledge and indicates the need for further investigation as follows:

a) Determination of the impact of bulk density and depth of tillage on heat transmission under soil solarisation technology;

b) Assessment of the economic incentives (prices and the ability to be subsidised) and biophysical aspects (soil quality) of plastic mulches;

c) Estimation of soil thermal-physical properties under the influence of different soil solarisation management scenarios (mulch type, tillage system, and fertiliser type);

d) Exploration of the effects of soil solarisation technology on soil thermal diffusivity, flux density, thermal conductivity, and volumetric heat capacity.

\section{ACKNOWLEDGEMENTS}

We would like to express sincere thanks to the Government and Ministry of Higher Education and Scientific Research, Iraq, for providing funding for this study as a $\mathrm{PhD}$ scholarship for the first author, Ahmed Abed Gatea Al-Shammary. Moreover, we would like to thank the reviewers and the editor for their time and efforts invested in our manuscript, and for providing constructive comments.

Funding: This study was funded by the Government and the Ministry of Higher Education and Scientific Research, Iraq.

Conflict of Interest: The authors declare that they have no conflict of interest.

\section{REFERENCES}

Abouziena, H. (2015). Allelopathic effects of sawdust, rice straw, bur-clover weed and cogongrass on weed control and development of onion. International Journal of Chemical and Technology Research 7, 337-345.

Abu-Hamdeh, N. H. (2000). Effect of tillage treatments on soil thermal conductivity for some Jordanian clay loam and loam soils. Soil and Tillage Research 56, 145-151.

Abu-Hamdeh, N. H. (2003). Thermal properties of soils as affected by density and water content. Biosystems engineering 86, 97-102. 
Abu-Irmaileh, B. (1991). Soil solarization controls broomrapes (Orobanche spp.) in host vegetable crops in the Jordan Valley. Weed Technology 5, 575-581.

Abzalov, M. (2016). Dry Bulk Density (DBD) of Rocks. In "Applied Mining Geology", pp. 97-110. Springer International Publishing, Cham.

Adekiya, A. O., Agbede, T. M., Aboyeji, C. M., and Dunsin, O. (2017). Response of okra (Abelmoschus esculentus (L.) Moench) and soil properties to different mulch materials in different cropping seasons. Scientia Horticulturae 217, 209-216.

Adhikari, R., Bristow, K. L., Casey, P. S., Freischmidt, G., Hornbuckle, J. W., and Adhikari, B. (2016). Preformed and sprayable polymeric mulch film to improve agricultural water use efficiency. Agricultural water management 169, 1-13.

Ahmed, M. A., Kroener, E., Benard, P., Zarebanadkouki, M., Kaestner, A., and Carminati, A. (2016). Drying of mucilage causes water repellency in the rhizosphere of maize: measurements and modelling. Plant and soil 407, 161-171.

Al-Kayssi, A., and Al-Karaghouli, A. (2002). A new approach for soil solarization by using paraffin-wax emulsion as a mulching material. Renewable energy 26, 637-648.

Al-Kayssi, A. W., Al-Karaghouli, A. A., Hasson, A. M., and Beker, S. A. (1990). Influence of soil moisture content on soil temperature and heat storage under greenhouse conditions. Journal of Agricultural Engineering Research 45, 241-252.

Al-Shammary, A. A. G., and Al-Sadoon, J. N. A. (2014). Influence of tillage depth, soil mulching systems and fertilizers on some thermal properties of silty clay soil. European Journal of Agriculture and Forestry Research 2, 1-16.

Al-Shammary, A. A. G., Al-Sadoon, J. N. A., and Lahmod, N. R. (2016). Influence of the Soil Solarization Management and Fertilizer on Soil Temperature under Different Soil Tillage Systems. Journal of Agricultural Science 8, 98.

Al-Shammary, A. A. G., Kouzani, A., Kaynak, A., Khoo, S. Y., and Norton, M. (2017). Experimental Investigation of Thermo-Physical Properties of Soil Using Solarisation Technology. American Journal of Applied Sciences 14, 649.661.

Allmaras, R., Hallauer, E., Nelson, W., and Evans, S. (1977). Surface energy balance and soil thermal property modifications by tillage-induced soil structure. Vol. 306, pp. 40. Minnesota Agricultural Experiment Station, Retrieved from the University of Minnesota Digital Conservancy.

Alrtimi, A., Rouainia, M., and Haigh, S. (2016). Thermal conductivity of a sandy soil. Applied Thermal Engineering 106, 551-560.

An, T., Schaeffer, S., Li, S., Fu, S., Pei, J., Li, H., Zhuang, J., Radosevich, M., and Wang, J. (2015). Carbon fluxes from plants to soil and dynamics of microbial immobilization under plastic film mulching and fertilizer application using 13C pulse-labeling. Soil Biology Biochemistry 80, 53-61.

Anikwe, M., Mbah, C., Ezeaku, P., and Onyia, V. (2007). Tillage and plastic mulch effects on soil properties and growth and yield of cocoyam (Colocasia esculenta) on an ultisol in southeastern Nigeria. Soil and Tillage Research 93, 264-272.

Arkhangelskaya, T., and Lukyashchenko, K. (2018). Estimating soil thermal diffusivity at different water contents from easily available data on soil texture, bulk density, and organic carbon content. Biosystems Engineering 168, 83-95.

Ashrafuzzaman, M., Halim, M. A., Ismail, M. R., Shahidullah, S., and Hossain, M. A. (2011). Effect of plastic mulch on growth and yield of chilli (Capsicum annuum L.). Brazilian Archives of Biology and Technology 54, 321-330.

Azooz, R. H., Lowery, B., Daniel, T. C., and Arshad, M. A. (1997). Impact of tillage and residue management on soil heat flux. Agricultural and Forest Meteorology 84, 207-222. 
Badía, D., López-García, S., Martí, C., Ortíz-Perpiñá, O., Girona-García, A., and Casanova-Gascón, J. (2017). Burn effects on soil properties associated to heat transfer under contrasting moisture content. Science of The Total Environment 601-602, 1119-1128.

Bai, J., Wang, J., Chen, X., Luo, G., Shi, H., Li, L., and Li, J. (2015). Seasonal and inter-annual variations in carbon fluxes and evapotranspiration over cotton field under drip irrigation with plastic mulch in an arid region of Northwest China. Journal of Arid Land 7, 272-284.

Barrera Necha, L. L., and Bautista-Baños, S. (2016). Chapter 8 - Prospects for the Use of Chitosan and Other Alternatives in Ornamental Conservation. In "Chitosan in the Preservation of Agricultural Commodities" (S. Bautista-Baños, G. Romanazzi and A. Jiménez-Aparicio, eds.), pp. 221-249. Academic Press, San Diego.

Barry-Macaulay, D., Bouazza, A., Wang, B., and Singh, R. (2015). Evaluation of soil thermal conductivity models. Canadian Geotechnical Journal 52, 1892-1900.

Basallote-Ureba, M. J., and Melero-Vara, J. (1993). Control of garlic white rot by soil solarization. Crop Protection 12, 219-223.

Ben-Yephet, Y., Melero-Vera, J., and DeVay, J. (1988). Interaction of soil solarization and methamsodium in the destruction of Verticillium dahliae and Fusarium oxysporum f. sp. vasinfectum. Crop Protection 7, 327-331.

Benlioglu, S., Boz, O., Yildiz, A., Kaskavalci, G., and Benlioglu, K. (2002). Soil solarization options in Aydin strawberry without methyl bromide. In "Proceedings Annual International Research Conference on Methyl Bromide Alternatives and Emissions Reductions", pp. 6-8.

Bi, J., Zhang, M., Chen, W., Lu, J., and Lai, Y. (2018). A new model to determine the thermal conductivity of fine-grained soils. International Journal of Heat and Mass Transfer 123, 407-417.

Blanco-Canqui, H., and Ruis, S. J. (2018). No-tillage and soil physical environment. Geoderma 326, 164200.

Bottinelli, N., Angers, D. A., Hallaire, V., Michot, D., Le Guillou, C., Cluzeau, D., Heddadj, D., and Menasseri-Aubry, S. (2017). Tillage and fertilization practices affect soil aggregate stability in a Humic Cambisol of Northwest France. Soil and Tillage Research 170, 14-17.

Braida, J. A., Reichert, J. M., Reinert, D. J., and Sequinatto, L. (2008). Elasticidade do solo em função da umidade e do teor de carbono orgânico. Revista Brasileira de Ciência do Solo 32.

Braunack, M., Johnston, D., Price, J., and Gauthier, E. J. F. C. R. (2015). Soil temperature and soil water potential under thin oxodegradable plastic film impact on cotton crop establishment and yield. Field Crops Research 184, 91-103.

Buyer, J. S., Teasdale, J. R., Roberts, D. P., Zasada, I. A., and Maul, J. E. (2010). Factors affecting soil microbial community structure in tomato cropping systems. Soil Biology Biochemistry 42, 831841.

Candido, V., D'Addabbo, T., Miccolis, V., and Castronuovo, D. (2011). Weed control and yield response of soil solarization with different plastic films in lettuce. Scientia Horticulturae 130, 491-497.

Carrieri, R., Raimo, F., Pentangelo, A., and Lahoz, E. (2013). Fusarium proliferatum and Fusarium tricinctum as causal agents of pink rot of onion bulbs and the effect of soil solarization combined with compost amendment in controlling their infections in field. Crop protection 43, 31-37.

Castello, I., D'Emilio, A., Raviv, M., and Vitale, A. (2017). Soil solarization as a sustainable solution to control tomato Pseudomonads infections in greenhouses. Agronomy for Sustainable Development 37, 59.

Celik, I., Gunal, H., Budak, M., and Akpinar, C. (2010). Effects of long-term organic and mineral fertilizers on bulk density and penetration resistance in semi-arid Mediterranean soil conditions. Geoderma 160, 236-243. 
Cerdà, A., González-Pelayo, Ó., Giménez-Morera, A., Jordán, A., Pereira, P., Novara, A., Brevik, E. C., Prosdocimi, M., Mahmoodabadi, M., and Keesstra, S. J. S. R. (2016). Use of barley straw residues to avoid high erosion and runoff rates on persimmon plantations in Eastern Spain under low frequency-high magnitude simulated rainfall events. Soil Research 54, 154-165.

Cerdà, A., Rodrigo-Comino, J., Giménez-Morera, A., and Keesstra, S. D. (2018a). Hydrological and erosional impact and farmer's perception on catch crops and weeds in citrus organic farming in Canyoles river watershed, Eastern Spain. Agriculture, Ecosystems \& Environment 258, 49-58.

Cerdà, A., Rodrigo-Comino, J., Giménez-Morera, A., Novara, A., Pulido, M., Kapović-Solomun, M., and Keesstra, S. (2018b). Policies can help to apply successful strategies to control soil and water losses. The case of chipped pruned branches (CPB) in Mediterranean citrus plantations. Land Use Policy 75, 734-745.

Chang-Rong, Y., En-Ke, L., Fan, S., Liu, Q., Liu, S., and Wen-Qing, H. (2014). Review of agricultural plastic mulching and its residual pollution and prevention measures in China. Journal of Agriculture Resources Environment 31, 95.

Chaudhari, P. R., Ahire, D. V., Ahire, V. D., Chkravarty, M., and Maity, S. (2013). Soil bulk density as related to soil texture, organic matter content and available total nutrients of Coimbatore soil. International Journal of Scientific and Research Publications 3, 1-8.

Chen, Y., Gamliel, A., Stapleton, J., and Aviad, T. (1991). Chemical. physical. and microbial changes related to plant growth in disinfested soil. In "Soil solarization", Vol. 1, pp. 103-129.

Chen, Y., and Katan, j. (1980). Effect of solar heating of soils by transparent polyethylene mulching on their chemical properties. Soil Science 130, 271-277.

Chen, Y., Liu, T., Tian, X., Wang, X., Li, M., Wang, S., and Wang, Z. (2015a). Effects of plastic film combined with straw mulch on grain yield and water use efficiency of winter wheat in Loess Plateau. Field Crops Research 172, 53-58.

Chen, Y., Wang, M., Zhou, S., Hu, R., and Zhou, C. (2015b). An effective thermal conductivity model for unsaturated compacted bentonites with consideration of bimodal shape of pore size distribution. Science China Technological Sciences 58, 369-380.

Cohen, O., Gamliel, A., Katan, J., Kurzbaum, E., Riov, J., and Bar, P. (2018). Controlling the seed bank of the invasive plant Acacia saligna: comparison of the efficacy of prescribed burning, soil solarization, and their combination. Biological invasions 20, 2875-2887.

Colaizzi, P. D., Evett, S. R., Agam, N., Schwartz, R. C., and Kustas, W. P. (2016). Soil heat flux calculation for sunlit and shaded surfaces under row crops: 1. Model development and sensitivity analysis. Agricultural and Forest Meteorology 216, 115-128.

Copec, K., Filipovic, D., Husnjak, S., Kovacev, I., and Kosutic, S. (2015). Effects of tillage systems on soil water content and yield in maize and winter wheat production. Plant, Soil Environment 61, 213219.

Costa, C. A., Guiné, R. P. F., Costa, D. V. T. A., Correia, H. E., and Nave, A. (2019). Chapter 3 - Pest Control in Organic Farming. In "Organic Farming" (S. Chandran, M. R. Unni and S. Thomas, eds.), pp. 4190. Woodhead Publishing.

Cuello, J. P., Hwang, H. Y., Gutierrez, J., Kim, S. Y., and Kim, P. J. (2015). Impact of plastic film mulching on increasing greenhouse gas emissions in temperate upland soil during maize cultivation. Applied soil ecology 91, 48-57.

D. Hemphill, D. (1993). "Agricultural Plastics as Solid Waste: What are the Options for Disposal?." D’Addabbo, T., Miccolis, V., Basile, M., and Candido, V. (2010). Soil Solarization and Sustainable Agriculture. In "Sociology, Organic Farming, Climate Change and Soil Science" (E. Lichtfouse, ed.), pp. 217-274. Springer Netherlands, Dordrecht. 
da Silva, D. M. N., Venturim, C. H. P., Valory Capucho, M. E. O., de Oliveira, F. L., and de Sá Mendonça, E. (2018). Impact of soil cover systems on soil quality and organic production of yacon. Scientia Horticulturae 235, 407-412.

Dagois, R., Faure, P., Bataillard, P., Bouzouidja, R., Coussy, S., Leguédois, S., Enjelvin, N., and Schwartz, C. (2017). From atmospheric-to pedo-climate modeling in Technosols: A global scale approach. Geoderma 301, 47-59.

Dai, Y., Kondo, M., Ito, K., Yoshiyama, K., Zhang, P., Zhang, F., and Senge, M. (2014). Study on Irrigation Water Requirements for the Control of <i>Ralstonia solanacearum </i>via Soil Solarization in Managing Tomato Cultivation. Transactions of The Japanese Society of Irrigation, Drainage and Rural Engineering 82, 433-440.

Davidson, E., and Janssens, I. (2006). Temperature Sensitivity of Soil Carbon Decomposition and Feedbacks to Climate Change. Nature 440, 165-73.

Dec, D., Dörner, J., and Horn, R. (2009). Effect of soil management on their thermal properties. J. Soil Sci. Plant Nutr 9, 26-39.

Di Prima, S., Marrosu, R., Lassabatere, L., Angulo-Jaramillo, R., and Pirastru, M. (2018). In situ characterization of preferential flow by combining plot-and point-scale infiltration experiments on a hillslope. Journal of hydrology 563, 633-642.

Díaz-Hernández, J., and Salmerón, T. (2012). Effects of a plastic cover on soil moisture change in a M editerranean climatic regime. Soil Use Management 28, 596-605.

Dong, H., Li, W., Tang, W., and Zhang, D. (2008). Furrow seeding with plastic mulching increases stand establishment and lint yield of cotton in a saline field. Agronomy Journal 100, 1640-1646.

Dong, H., Li, W., Tang, W., and Zhang, D. (2009). Early plastic mulching increases stand establishment and lint yield of cotton in saline fields. Field Crops Research 111, 269-275.

Dong, Q. g., Yang, Y., Yu, K., and Feng, H. (2018). Effects of straw mulching and plastic film mulching on improving soil organic carbon and nitrogen fractions, crop yield and water use efficiency in the Loess Plateau, China. Agricultural Water Management 201, 133-143.

Downie, H. F., Adu, M., Schmidt, S., Otten, W., Dupuy, L. X., White, P., and Valentine, T. A. (2015). Challenges and opportunities for quantifying roots and rhizosphere interactions through imaging and image analysis. Plant, cell \& environment 38, 1213-1232.

Dunbabin, V. M., Postma, J. A., Schnepf, A., Pagès, L., Javaux, M., Wu, L., Leitner, D., Chen, Y. L., Rengel, Z., and Diggle, A. (2013). Modelling root-soil interactions using three-dimensional models of root growth, architecture and function. Plant and soil 372, 93-124.

Ekebafe, L., Ogbeifun, D., and Okieimen, F. (2011). Polymer applications in agriculture. Biokemistri 23.

Evett, S. R., Agam, N., Kustas, W. P., Colaizzi, P. D., and Schwartz, R. C. (2012). Soil profile method for soil thermal diffusivity, conductivity and heat flux: Comparison to soil heat flux plates. Advances in Water Resources 50, 41-54.

Fenoll, J., Ruiz, E., Hellín, P., Navarro, S., and Flores, P. (2010). Solarization and biosolarization enhance fungicide dissipation in the soil. Chemosphere 79, 216-220.

Figueiredo, P. G., Bicudo, S. J., Chen, S., Fernandes, A. M., Tanamati, F. Y., and Djabou-Fondjo, A. S. M. (2017). Effects of tillage options on soil physical properties and cassava-dry-matter partitioning. Field Crops Research 204, 191-198.

Flores, P., Castellar, I., Hellín, P., Fenoll, J., and Navarro, J. (2007). Response of pepper plants to different rates of mineral fertilizers after soil biofumigation and solarization. Journal of plant nutrition $\mathbf{3 0}$, 367-379.

Forter, I., and Merriman, P. (1985). Evaluation of soil solarization for control of root diseases of row crops in Victoria. Plant Pathology 34, 108-118. 
Gamliel, A., Austerweil, M., and Kritzman, G. (2000). Non-chemical approach to soilborne pest management-organic amendments. Crop Protection 19, 847-853.

Gamliel, A., and Katan, J. (2005). DISINFESTATION. In "Encyclopedia of Soils in the Environment" (D. Hillel, ed.), pp. 394-400. Elsevier, Oxford.

Gamliel, A., and Stapleton, J. (1993). Characterization of antifungal volatile compounds evolved from solarized soil amended with cabbage residues. Phytopathology 83, 899-905.

Gao, H., Yan, C., Liu, Q., Ding, W., Chen, B., and Li, Z. (2019). Effects of plastic mulching and plastic residue on agricultural production: A meta-analysis. Science of The Total Environment 651, 484492.

Gatea, A. A. (2010). Design, construction and performance evaluation of solar maize dryer. Journal of Agricultural Biotechnology and sustainable development 2, 39-46.

Gill, H. K. (2014). Soil Solarization: A Natural Pest Management Strategy. Popular Kheti 2, 153-157.

Głąb, T., and Kulig, B. (2008). Effect of mulch and tillage system on soil porosity under wheat (Triticum aestivum). Soil and Tillage Research 99, 169-178.

Gnatowski, T. (2009). Analysis of thermal diffusivity data determined for selected organic topsoil layer. Annals of Warsaw University of Life Sciences-SGGW. Land Reclamation 41, 95-107.

Goldberger, J., Jones, R., Miles, C., W. Wallace, R., and A. Inglis, D. (2015). Barriers and Bridges to the Adoption of Biodegradable Plastic Mulches for US Specialty Crop Production. Renewable Agriculture and Food Systems 30, 143-153.

Gong, D., Hao, W., Mei, X., Gao, X., Liu, Q., and Caylor, K. (2015). Warmer and wetter soil stimulates assimilation more than respiration in rainfed agricultural ecosystem on the China Loess Plateau: the role of partial plastic film mulching tillage. PloS one 10, e0136578.

Grünzweig, J. M., Katan, J., Ben-Tal, Y., and Rabinowitch, H. D. (1999). The role of mineral nutrients in the increased growth response of tomato plants in solarized soil. Plant and Soil 206, 21-27.

Guo, L.-J., Zhang, Z.-S., Wang, D.-D., Li, C.-F., and Cao, C.-G. (2015). Effects of short-term conservation management practices on soil organic carbon fractions and microbial community composition under a rice-wheat rotation system. Biology and fertility of soils 51, 65-75.

Guo, L., Wu, G., Li, Y., Li, C., Liu, W., Meng, J., Liu, H., Yu, X., and Jiang, G. (2016). Effects of cattle manure compost combined with chemical fertilizer on topsoil organic matter, bulk density and earthworm activity in a wheat-maize rotation system in Eastern China. Soil and Tillage Research 156, 140-147.

Ham, J. M., Kluitenberg, G., and Lamont, W. (1993). Optical properties of plastic mulches affect the field temperature regime. Journal of the American Society for Horticultural Science 118, 188-193.

Haraguchi, T., Marui, A., Yuge, K., Nakano, Y., and Mori, K. (2004). Effect of plastic-film mulching on leaching of nitrate nitrogen in an upland field converted from paddy. Paddy and Water Environment 2, 67-72.

Hayes, D. G., Dharmalingam, S., Wadsworth, L. C., Leonas, K. K., Miles, C., and Inglis, D. A. (2012). Biodegradable agricultural mulches derived from biopolymers. In "Degradable Polymers and Materials: Principles and Practice (2nd Edition)", pp. 201-223. ACS Publications.

Haynes, R. J., and Naidu, R. (1998). Influence of lime, fertilizer and manure applications on soil organic matter content and soil physical conditions: a review. Nutrient cycling in agroecosystems $\mathbf{5 1}$, 123-137.

Hillel, D. (2003). "Introduction to environmental soil physics," Elsevier.

Hu, G., Zhao, L., Wu, X., Li, R., Wu, T., Xie, C., Qiao, Y., Shi, J., Li, W., and Cheng, G. (2016). New Fourierseries-based analytical solution to the conduction-convection equation to calculate soil temperature, determine soil thermal properties, or estimate water flux. International Journal of Heat and Mass Transfer 95, 815-823. 
Huo, L., Pang, H., Zhao, Y., Wang, J., Lu, C., and Li, Y. (2017). Buried straw layer plus plastic mulching improves soil organic carbon fractions in an arid saline soil from Northwest China. Soil and Tillage Research 165, 286-293.

Ibarra-Jiménez, L., Lira-Saldivar, R. H., Valdez-Aguilar, L. A., and Lozano-Del Río, J. (2011). Colored plastic mulches affect soil temperature and tuber production of potato. Acta Agriculturae Scandinavica, Section B-Soil Plant Science 61, 365-371.

Ibarra-Jiménez, L., Valdez-Aguilar, L. A., Cárdenas-Flores, A., Lira-Saldivar, H., Lozano-del Río, J., and Cavazos, C. L. (2012). Influence of double cropping on growth and yield of dry beans with colored plastic mulches. Chilean Journal of Agricultural Research 72, 470.

Ingman, M., Santelmann, M. V., and Tilt, B. (2015). Agricultural water conservation in China: plastic mulch and traditional irrigation. Ecosystem Health and Sustainability 1, 1-11.

Ito, K., Onishi, T., and Senge, M. (2011). Soil properties affected by combinations of soil solarization and organic amendment. Paddy and Water Environment 9, 357-366.

J. Ruhoff, P., Perumal, P., and T. Perumal, P. (2014). Blends of acrylic latices and polyurethane dispersions for coatings. (U.S, ed.), Vol. 8,637,609, U.S.

Jabran, K., Hussain, M., Fahad, S., Farooq, M., Bajwa, A. A., Alharrby, H., and Nasim, W. (2016). Economic assessment of different mulches in conventional and water-saving rice production systems. Environmental Science and Pollution Research 23, 9156-9163.

Jabro, J. D., Iversen, W. M., Stevens, W. B., Evans, R. G., Mikha, M. M., and Allen, B. L. (2016). Physical and hydraulic properties of a sandy loam soil under zero, shallow and deep tillage practices. Soil and Tillage Research 159, 67-72.

Jia, G. S., Tao, Z. Y., Meng, X. Z., Ma, C. F., Chai, J. C., and Jin, L. W. (2019). Review of effective thermal conductivity models of rock-soil for geothermal energy applications. Geothermics 77, 1-11.

Jiang, X. J., Liu, W., Wang, E., Zhou, T., and Xin, P. (2017). Residual plastic mulch fragments effects on soil physical properties and water flow behavior in the Minqin Oasis, northwestern China. Soil and Tillage Research 166, 100-107.

Jordán, A., Zavala, L. M., and Gil, J. (2010). Effects of mulching on soil physical properties and runoff under semi-arid conditions in southern Spain. Catena 81, 77-85.

Kader, M. A., Senge, M., Mojid, M. A., and Ito, K. (2017). Recent advances in mulching materials and methods for modifying soil environment. Soil and Tillage Research 168, 155-166.

Kanaan, H., Frenk, S., Raviv, M., Medina, S., and Minz, D. (2018). Long and short term effects of solarization on soil microbiome and agricultural production. Applied Soil Ecology 124, 54-61.

Karuma, A., Mtakwa, P., Amuri, N., Gachene, C. K., and Gicheru, P. (2014). Tillage effects on selected soil physical properties in a maize-bean intercropping system in Mwala District, Kenya. International scholarly research notices 2014.

Kasirajan, S., and Ngouajio, M. (2013). Erratum to: Polyethylene and biodegradable mulches for agricultural applications: a review. Agronomy for Sustainable Development 33, 443-443.

Katan, J. (2017). DISEASES CAUSED BY SOILBORNE PATHOGENS: BIOLOGY, MANAGEMENT AND CHALLENGES. Journal of Plant Pathology 99, 305-315.

Katan, J., and DeVay, J. E. (1991). "Soil solarization," cRC Press.

Katan, J., Greenberger, A., Alon, H., and Grinstein, A. (1976). Solar heating by polyethylene mulching for the control of diseases caused by soil-borne pathogens. Phytopathology 66, 683-688.

Keesstra, S., Nunes, J., Novara, A., Finger, D., Avelar, D., Kalantari, Z., and Cerdà, A. (2018). The superior effect of nature based solutions in land management for enhancing ecosystem services. Science of the Total Environment 610, 997-1009. 
Kim, Y., Berger, S., Kettering, J., Tenhunen, J., Haas, E., and Kiese, R. (2014). Simulation of N2O emissions and nitrate leaching from plastic mulch radish cultivation with LandscapeDNDC. Ecological research 29, 441-454.

Kipfer, T., Egli, S., Ghazoul, J., Moser, B., and Wohlgemuth, T. (2010). Susceptibility of ectomycorrhizal fungi to soil heating. Fungal Biology 114, 467-472.

Kitiş, Y. (2011). Mulch and solarization applications in weed control. In "GAP VI conference of agriculture, Şanlıurfa", pp. 9-12.

Kuzucu, M., and Dökmen, F. (2015). The effects of tillage on soil water content in dry areas. Agriculture and agricultural science procedia 4, 126-132.

Lal Bhardwaj, R. (2013). Effect of mulching on crop production under rainfed condition-a review. Agricultural Reviews 34.

Lamond, J. F., and Pielert, J. H. (2006). Significance of tests and properties of concrete and concretemaking materials. ASTM West Conshohocken, PA.

Lampurlanés, J., Plaza-Bonilla, D., Álvaro-Fuentes, J., and Cantero-Martínez, C. (2016). Long-term analysis of soil water conservation and crop yield under different tillage systems in Mediterranean rainfed conditions. Field crops research 189, 59-67.

Leib, B., Jarrett, A., Orzolek, M., and Mumma, R. (2000). Drip chemigation of imidacloprid under plastic mulch increased yield and decreased leaching caused by rainfall. Transactions of the ASAE 43, 615.

Levitan, L., and Barros, A. (2003). Recycling Agricultural Plastics in New York State.

Levy, J. S., and Schmidt, L. M. (2016). Thermal properties of Antarctic soils: wetting controls subsurface thermal state. Antarctic Science, 1-10.

Li, F.-M., Wang, J., Xu, J.-Z., and Xu, H.-L. (2004). Productivity and soil response to plastic film mulching durations for spring wheat on entisols in the semiarid Loess Plateau of China. Soil and Tillage Research 78, 9-20.

Liang, H., Hu, K., Qin, W., Zuo, Q., and Zhang, Y. (2017). Modelling the effect of mulching on soil heat transfer, water movement and crop growth for ground cover rice production system. Field Crops Research 201, 97-107.

Licht, M. A., and Al-Kaisi, M. (2005). Strip-tillage effect on seedbed soil temperature and other soil physical properties. Soil and Tillage Research 80, 233-249.

Liebman, M., and Gallandt, E. R. (1997). 9 - Many Little Hammers: Ecological Management of Crop-Weed Interactions. In "Ecology in Agriculture" (L. E. Jackson, ed.), pp. 291-343. Academic Press.

Liu, E., He, W., and Yan, C. (2014a). 'White revolution'to 'white pollution'-agricultural plastic film mulch in China. Environmental Research Letters 9, 091001.

Liu, H., Wang, B., and Fu, C. (2008). Relationships between surface albedo, soil thermal parameters and soil moisture in the semi-arid area of Tongyu, northeastern China. Advances in Atmospheric Sciences 25, 757-764.

Liu, J., Bu, L., Zhu, L., Luo, S., Chen, X., and Li, S. (2014b). Optimizing plant density and plastic film mulch to increase maize productivity and water-use efficiency in semiarid areas. Agronomy Journal 106, 1138-1146.

Liu, Z., Xu, J., Li, X., and Wang, J. (2018). Mechanisms of biochar effects on thermal properties of red soil in south China. Geoderma 323, 41-51.

Lobell, D. B., and Field, C. B. (2007). Global scale climate-crop yield relationships and the impacts of recent warming. Environmental research letters 2, 014002.

Luo, S., Zhu, L., Liu, J., Bu, L., Yue, S., Shen, Y., and Li, S. (2015). Sensitivity of soil organic carbon stocks and fractions to soil surface mulching in semiarid farmland. European Journal of Soil Biology 67, 35-42. 
1011

1012

1013

1014

1015

1016

1017

1018

1019

1020

1021

1022

1023

1024

1025

1026

1027

1028

1029

1030

1031

1032

1033

1034

1035

1036

1037

1038

1039

1040

1041

1042

1043

1044

1045

1046

1047

1048

1049

1050

1051

1052

1053

1054

1055

1056

Luo, Z., Wang, E., and Sun, O. (2010). Can no-tillage stimulate carbon sequestration in agricultural soils? A meta-analysis of paired experiments. Agriculture, ecosystems environment 139, 224-231.

Łydżba, D., Różański, A., Rajczakowska, M., and Stefaniuk, D. (2017). Random checkerboard based homogenization for estimating effective thermal conductivity of fully saturated soils. Journal of Rock Mechanics Geotechnical Engineering 9, 18-28.

Maharjan, G. R., Prescher, A.-K., Nendel, C., Ewert, F., Mboh, C. M., Gaiser, T., and Seidel, S. J. (2018). Approaches to model the impact of tillage implements on soil physical and nutrient properties in different agro-ecosystem models. Soil and Tillage Research 180, 210-221.

Mahdavi, S. M., Neyshabouri, M. R., Fujimaki, H., and Heris, A. M. (2017). Coupled heat and moisture transfer and evaporation in mulched soils. Catena 151, 34-48.

Mahrer, Y., Naot, O., Rawitz, E., and Katan, J. (1984). Temperature and Moisture Regimes in Soils Mulched with Transparent Polyethylene 1. Soil Science Society of America Journal 48, 362-367.

Makarychev, S. V., and Bolotov, A. G. (2017). Conductive and steam-diffuse constituents of thermotransfer in different soil moisture contents: case study of the Altai Region's soils. Eurasian Journal of Soil Science 6, 44.

Malinconico, M., Immirzi, B., Santagata, G., Schettini, E., Vox, G., and Scarascia Mugnozza, G. (2008). An overview on innovative biodegradable materials for agricultural applications. Progress in polymer degradation and stability research 69-114.

McKenzie, C., Lapointe, S., and Duncan, L. (2001). Landscape fabric as a physical barrier to neonate Diaprepes abbreviatus (Coleoptera: Curculionidae). Florida Entomologist 84, 721.

McLean, K. L., Swaminathan, J., and Stewart, A. (2001). Increasing soil temperature to reduce sclerotial viability of Sclerotium cepivorum in New Zealand soils. Soil Biology and Biochemistry 33, 137143.

Mei-Xian, L., Jing-Song, Y., Xiao-Ming, L., Mei, Y., and Jin, W. (2013). Numerical simulation of soil water dynamics in a drip irrigated cotton field under plastic mulch. Pedosphere 23, 620-635.

Melero-Vara, J., Blanco, M., Bejarano-AlcÁZar, J., and Jiménez-Díaz, R. (2007). Control of Verticillium wilt of cotton by means of soil solarization and tolerant cultivars in southern Spain. Plant Pathology 44, 250-260.

Mengistu, A. G., van Rensburg, L. D., and Mavimbela, S. S. W. (2017). The effect of soil water and temperature on thermal properties of two soils developed from aeolian sands in South Africa. CATENA 158, 184-193.

Merante, P., Dibari, C., Ferrise, R., Sánchez, B., Iglesias, A., Lesschen, J. P., Kuikman, P., Yeluripati, J., Smith, P., and Bindi, M. (2017). Adopting soil organic carbon management practices in soils of varying quality: Implications and perspectives in Europe. Soil and Tillage Research 165, 95-106.

Merfield, C. N. (2019). Chapter 5 - Integrated Weed Management in Organic Farming. In "Organic Farming" (S. Chandran, M. R. Unni and S. Thomas, eds.), pp. 117-180. Woodhead Publishing.

Mitchell, J. P., Shrestha, A., Mathesius, K., Scow, K. M., Southard, R. J., Haney, R. L., Schmidt, R., Munk, D. S., and Horwath, W. R. (2017). Cover cropping and no-tillage improve soil health in an arid irrigated cropping system in California's San Joaquin Valley, USA. Soil and Tillage Research 165, 325-335.

Miyajima, S., Uoi, N., Murata, T., Takeda, M., Morishima, W., and Watanabe, M. (2015). Effect of structural modification on heat transfer through man-made soils in urban green areas. Soil science and plant nutrition 61, 70-87.

Mondal, S., Padmakumar, G., Sharma, V., Singh, D. N., and Baghini, M. S. (2016). A methodology to determine thermal conductivity of soils from flux measurement. Geomechanics and Geoengineering 11, 73-85. 
Moreno, M., and Moreno, A. (2008). Effect of different biodegradable and polyethylene mulches on soil properties and production in a tomato crop. Scientia Horticulturae 116, 256-263.

Morra, L., Carrieri, R., Fornasier, F., Mormile, P., Rippa, M., Baiano, S., Cermola, M., Piccirillo, G., and Lahoz, E. (2018). Solarization working like a "solar hot panel" after compost addition sanitizes soil in thirty days and preserves soil fertility. Applied Soil Ecology 126, 65-74.

Mulumba, L. N., and Lal, R. (2008). Mulching effects on selected soil physical properties. Soil and Tillage Research 98, 106-111.

Muñoz-Romero, V., Benítez-Vega, J., López-Bellido, R. J., Fontán, J. M., and López-Bellido, L. (2010). Effect of tillage system on the root growth of spring wheat. Plant and soil 326, 97-107.

Muñoz, K., Schmidt-Heydt, M., Stoll, D., Diehl, D., Ziegler, J., Geisen, R., and Schaumann, G. E. (2015). Effect of plastic mulching on mycotoxin occurrence and mycobiome abundance in soil samples from asparagus crops. Mycotoxin Research 31, 191-201.

Mutetwa, M., and Mtaita, T. (2014). Effects of mulching and fertilizer sources on growth and yield of onion. J. Glob. Innov. Agric. Soc. Sci 2, 102-106.

Nishigaki, T., Shibata, M., Sugihara, S., Mvondo-Ze, A. D., Araki, S., and Funakawa, S. (2017). Effect of mulching with vegetative residues on soil water erosion and water balance in an oxisol cropped by cassava in east cameroon. Land Degradation \& Development 28, 682-690.

Nzeyimana, I., Hartemink, A. E., Ritsema, C., Stroosnijder, L., Lwanga, E. H., and Geissen, V. (2017). Mulching as a strategy to improve soil properties and reduce soil erodibility in coffee farming systems of Rwanda. Catena 149, 43-51.

O'Kelly, B. C., and Sivakumar, V. (2014). Water content determinations for peat and other organic soils using the oven-drying method. Drying technology 32, 631-643.

Oberholzer, S., Prasuhn, V., and Hund, A. (2017). Crop water use under Swiss pedoclimatic conditionsEvaluation of lysimeter data covering a seven-year period. Field Crops Research 211, 48-65.

Odó Camps, J., and Concepción Ramos, M. (2011). Grape harvest and yield responses to inter-annual changes in temperature and precipitation in an area of north-east Spain with a Mediterranean climate. International journal of biometeorology 56, 853-64.

Ogundare, S., Babatunde, I., and Etukudo, O. (2015). Response of Tomato Variety (Roma F) Yield to Different Mulch Materials and Staking in Kabba, Kogi State, Nigeria. Journal of Agricultural Studies 3, 61-70.

Ordóñez, I., López, I. F., Kemp, P. D., Descalzi, C. A., Horn, R., Zúñiga, F., Dec, D., and Dörner, J. (2018). Effect of pasture improvement managements on physical properties and water content dynamics of a volcanic ash soil in southern Chile. Soil and Tillage Research 178, 55-64.

ÖZ, H. (2018). A new approach to soil solarization: Addition of biochar to the effect of soil temperature and quality and yield parameters of lettuce (Lactuca Sativa L. Duna). Scientia Horticulturae 228, 153-161.

Oz, H., Coskan, A., and Atilgan, A. (2017). Determination of effects of various plastic covers and biofumigation on soil temperature and soil nitrogen form in greenhouse solarization: new solarization cover material. Journal of Polymers and the Environment 25, 370-377.

Ozpinar, S., Ozpinar, A., and Cay, A. (2018). Soil management effect on soil properties in traditional and mechanized vineyards under a semiarid Mediterranean environment. Soil and Tillage Research 178, 198-208.

Özyılmaz, Ü. (2019). Soil solarization simulator. Applied Soil Ecology 142, 59-63.

Pires, L. F., Borges, J. A., Rosa, J. A., Cooper, M., Heck, R. J., Passoni, S., and Roque, W. L. (2017). Soil structure changes induced by tillage systems. Soil and Tillage Research 165, 66-79. 
Pituello, C., Polese, R., Morari, F., and Berti, A. (2016). Outcomes from a long-term study on crop residue effects on plant yield and nitrogen use efficiency in contrasting soils. European journal of agronomy 77, 179-187.

Pramanik, P., Bandyopadhyay, K., Bhaduri, D., Bhatacharyya, R., and Aggarwal, P. (2015). Effect of mulch on soil thermal regimes-A review. International Journal of Agriculture, Environment and Biotechnology 8, 645.

Prosdocimi, M., Tarolli, P., and Cerdà, A. (2016). Mulching practices for reducing soil water erosion: A review. Earth-Science Reviews 161, 191-203.

Pullman, G., DeVay, J., Garber, R., and Weinhold, A. J. S.-B. P. P. (1979). Control of soil-borne fungal pathogens by plastic tarping of soil. In "INTERNATIONAL SYMPOSIUM ON FACTORS DETERMINING THE BEHAVIOUR OF PLANT PATHOGENS IN SOIL. PROCEEDINGS", Vol. 439. InistCNRS ; INRA, BAARN.

Qi, Z., Feng, H., Zhao, Y., Zhang, T., Yang, A., and Zhang, Z. (2018). Spatial distribution and simulation of soil moisture and salinity under mulched drip irrigation combined with tillage in an arid saline irrigation district, northwest China. Agricultural Water Management 201, 219-231.

Qin, W., Chi, B., and Oenema, O. (2013). Long-term monitoring of rainfed wheat yield and soil water at the loess plateau reveals low water use efficiency. PloS one 8, e78828.

R. Lemon, E. (1956). The Potentialities for Decreasing Soil Moisture Evaporation Loss1. Soil Science Society of America Journal 20, 120-125.

Rinot, O., Levy, G. J., Steinberger, Y., Svoray, T., and Eshel, G. (2019). Soil health assessment: A critical review of current methodologies and a proposed new approach. Science of The Total Environment 648, 1484-1491.

Rodrigo-Comino, J., Senciales, J. M., Cerdà, A., and Brevik, E. C. (2018). The multidisciplinary origin of soil geography: A review. Earth-Science Reviews 177, 114-123.

S. F. Ricci, M., L. de Almeida, D., de L. D. Ribeiro, R., M. de Aquino, A., C. Pereira, J., De-Polli, H., M. Reis, V., and R. Eklund, C. (1999). Cyperus rotundus Control by Solarization. Biological agriculture \& horticulture 17, 151-157.

Sabburg, R., Obanor, F., Aitken, E., and Chakraborty, S. (2015). Changing fitness of a necrotrophic plant pathogen under increasing temperature. Global change biology 21, 3126-3137.

Saglam, M., Sintim, H. Y., Bary, A. I., Miles, C. A., Ghimire, S., Inglis, D. A., and Flury, M. (2017). Modeling the effect of biodegradable paper and plastic mulch on soil moisture dynamics. Agricultural Water Management 193, 240-250.

Satour, M., Abdel-Rahim, M., El-Yamani, T., Radwan, A., Rabinowitch, H., Katan, J., and Grinstein, A. (1988). Soil solarization in onion fields in Egypt and Israel: short-and long-term effects. In "III International Symposium on Soil Desinfestation 255", pp. 151-160.

Satour, M., El-Sherif, E., El-Ghareeb, L., El-Hadad, S., and El-Wakil, H. (1991). Achievements of soil solarization in Egypt. FAO plant production protection paper, 200-212.

Schoenholtz, S. H., Van Miegroet, H., and Burger, J. (2000). A review of chemical and physical properties as indicators of forest soil quality: challenges and opportunities. Forest ecology and management 138, 335-356.

Shi, C.-h., Hu, J.-r., Wei, Q.-w., Yang, Y.-t., Cheng, J.-x., Han, H.-I., Wu, Q.-j., Wang, S.-I., Xu, B.-y., Su, Q., Li, C.-r., and Zhang, Y.-j. (2018). Control of Bradysia odoriphaga (Diptera: Sciaridae) by soil solarization. Crop Protection 114, 76-82.

Simmons, C. W., Claypool, J. T., Marshall, M. N., Jabusch, L. K., Reddy, A. P., Simmons, B. A., Singer, S. W., Stapleton, J. J., and VanderGheynst, J. S. (2014). Characterization of bacterial communities in solarized soil amended with lignocellulosic organic matter. Applied soil ecology 73, 97-104. 
Simmons, C. W., Higgins, B., Staley, S., Joh, L. D., Simmons, B. A., Singer, S. W., Stapleton, J. J., and VanderGheynst, J. S. (2016). The role of organic matter amendment level on soil heating, organic acid accumulation, and development of bacterial communities in solarized soil. Applied Soil Ecology 106, 37-46.

Sinkevičienè, A., Jodaugienè, D., Pupalienè, R., and Urbonienè, M. (2009). The influence of organic mulches on soil properties and crop yield. Agronomy Research 7, 485-491.

Smith, J. (1993). Soil organic matter dynamics and crop residue management. Soil microbial ecology, 6593.

Smith, P., Cotrufo, M., Rumpel, C., Paustian, K., Kuikman, P., Elliott, J., McDowell, R., Griffiths, R., Asakawa, S., and Bustamante, M. (2015). Biogeochemical cycles and biodiversity as key drivers of ecosystem services provided by soils. Soil Discussions 2, 537-586.

Sosnowski, M., Fletcher, J., Daly, A., Rodoni, B., and Viljanen-Rollinson, S. (2009). Techniques for the treatment, removal and disposal of host material during programmes for plant pathogen eradication. Plant Pathology 58, 621-635.

Stapleton, J., and E. DeVay, J. (1984). Thermal Components of Soil Solarization as Related to Changes in Soil and Root Microflora and Increased Plant Growth Response. Phytopathology 74, 255-259.

Stapleton, J., Elmore, C., and DeVay, J. (2000). Solarization and biofumigation help disinfest soil. California Agriculture 54, 42-45.

Stapleton, J. J. (2000). Soil solarization in various agricultural production systems. Crop Protection 19, 837-841.

Steinmetz, Z., Wollmann, C., Schaefer, M., Buchmann, C., David, J., Tröger, J., Muñoz, K., Frör, O., and Schaumann, G. E. (2016). Plastic mulching in agriculture. Trading short-term agronomic benefits for long-term soil degradation? Science of the total environment 550, 690-705.

Subrahmaniyan, K., Kalaiselvan, P., Balasubramanian, T., and Zhou, W. (2006). Crop productivity and soil properties as affected by polyethylene film mulch and land configurations in groundnut (Arachis hypogaea L.) (Einfluss von Polyethylenfilm-Mulch und Feldbeschaffenheit auf Ertrag und Bodeneigenschaften im Erdnussanbau [Arachis hypogaea L.]). Archives of Agronomy Soil Science 52, 79-103.

Sun, Q., Zhang, W., and Qian, H. (2016). Effects of high temperature thermal treatment on the physical properties of clay. Environmental Earth Sciences 75, 610.

Taparauskienè, L., and Miseckaitè, O. (2014). Effect of Mulch on Soil Moisture Depletion and Strawberry Yield in Sub-Humid Area. Polish Journal of Environmental Studies 23.

Teng, J., Yasufuku, N., Zhang, S., and He, Y. (2016). Modelling water content redistribution during evaporation from sandy soil in the presence of water table. Computers and Geotechnics 75, 210224.

Tesfaye, T., Tigabu, E., Germadu, Y., and Lemma, H. (2016). Effect of colored polyethylene mulch on soil temperature, growth, fruit quality and yield of tomato (Lycopersicon esculentum Mill.). World J. Agric. Sci 12, 161-166.

Tokoro, T., Ishikawa, T., Shirai, S., and Nakamura, T. (2016). Estimation methods for thermal conductivity of sandy soil with electrical characteristics. Soils and Foundations 56, 927-936.

Tong, B., Gao, Z., Horton, R., and Wang, L. (2017). Soil apparent thermal diffusivity estimated by conduction and by conduction-convection heat transfer models. Journal of Hydrometeorology 18, 109-118.

Tu, C., Ristaino, J. B., and Hu, S. (2006). Soil microbial biomass and activity in organic tomato farming systems: Effects of organic inputs and straw mulching. Soil Biology and Biochemistry38, 247-255. 
Usowicz, B., Lipiec, J., Łukowski, M., Marczewski, W., and Usowicz, J. (2016). The effect of biochar application on thermal properties and albedo of loess soil under grassland and fallow. Soil and Tillage Research 164, 45-51.

Usowicz, B., Lipiec, J., Usowicz, J. B., and Marczewski, W. (2013). Effects of aggregate size on soil thermal conductivity: Comparison of measured and model-predicted data. International Journal of Heat and Mass Transfer 57, 536-541.

Usowicz, B., Łukowski, M. I., Rüdiger, C., Walker, J. P., and Marczewski, W. (2017). Thermal properties of soil in the Murrumbidgee River Catchment (Australia). International Journal of Heat and Mass Transfer 115, 604-614.

van Lier, J., and Durigon, A. (2013). Soil thermal diffusivity estimated from data of soil temperature and single soil component properties. Revista Brasileira de Ciência do Solo 37, 106-112.

Vela, N., Fenoll, J., Navarro, G., Garrido, I., and Navarro, S. (2017). Trial of solar heating methods (solarization and biosolarization) to reduce persistence of neonicotinoid and diamide insecticides in a semiarid Mediterranean soil. Science of The Total Environment 590-591, 325332.

Waewsak, J., Chindaruksa, S., and Punlek, C. (2006). A mathematical modeling study of hot air drying for some agricultural products. Thammasat international Journal of science and Technology 11, 1420.

Wallace, K. J., and Jago, M. (2017). Category mistakes: A barrier to effective environmental management. Journal of environmental management 199, 13-20.

Wang, H., Wang, C., Zhao, X., and Wang, F. (2015). Mulching increases water-use efficiency of peach production on the rainfed semiarid Loess Plateau of China. Agricultural Water Management $154,20-28$.

Wang, X., Jia, Z., Liang, L., Yang, B., Ding, R., Nie, J., and Wang, J. (2016a). Impacts of manure application on soil environment, rainfall use efficiency and crop biomass under dryland farming. Scientific reports 6, 20994.

Wang, Y. P., Li, X. G., Fu, T., Wang, L., Turner, N. C., Siddique, K. H., and Li, F.-M. (2016b). Multi-site assessment of the effects of plastic-film mulch on the soil organic carbon balance in semiarid areas of China. Agricultural and forest meteorology228, 42-51.

Wilhelm, K., and Bockheim, J. (2016). Influence of soil properties on active layer thermal propagation along the western Antarctic Peninsula. Earth Surface Processes and Landforms 41, 1550-1563.

Williams, A., Davis, A. S., Ewing, P. M., Grandy, A. S., Kane, D. A., Koide, R. T., Mortensen, D. A., Smith, R. G., Snapp, S. S., and Spokas, K. A. (2016). A comparison of soil hydrothermal properties in zonal and uniform tillage systems across the US Corn Belt. Geoderma 273, 12-19.

Xie, Z., Wang, Y., Jiang, W., and Wei, X. (2006). Evaporation and evapotranspiration in a watermelon field mulched with gravel of different sizes in northwest China. Agricultural water management 81, 173-184.

Xiukang, W., Zhanbin, L., and Yingying, X. (2015). Effects of mulching and nitrogen on soil temperature, water content, nitrate- $\mathrm{N}$ content and maize yield in the Loess Plateau of China. Agricultural Water Management 161, 53-64.

Yamanaka, T., Inoue, M., and Kaihotsu, I. (2004). Effects of gravel mulch on water vapor transfer above and below the soil surface. Agricultural Water Management 67, 145-155.

Yang, N., Sun, Z.-X., Feng, L.-S., Zheng, M.-Z., Chi, D.-C., Meng, W.-Z., Hou, Z.-Y., Bai, W., and Li, K.-Y. (2015). Plastic film mulching for water-efficient agricultural applications and degradable films materials development research. Materials and Manufacturing Processes 30, 143-154. 
Yao, Y., Xue, Z., Hong, C., Zhu, F., Chen, X., Wang, W., Cai, Z., Huang, N., and Yang, X. (2016). Efficiency of different solarization-based ecological soil treatments on the control of Fusarium wilt and their impacts on the soil microbial community. Applied Soil Ecology 108, 341-351.

Yuan, C., Lei, T., Mao, L., Liu, H., and Wu, Y. (2009). Soil surface evaporation processes under mulches of different sized gravel. CATENA 78, 117-121.

Yun, T. S., and Santamarina, J. C. (2008). Fundamental study of thermal conduction in dry soils. Granular matter 10, 197.

Zhang, F., Zhang, W., Li, M., Zhang, Y., Li, F., and Li, C. (2017). Is crop biomass and soil carbon storage sustainable with long-term application of full plastic film mulching under future climate change? Agricultural Systems 150, 67-77.

Zhang, G., Zhang, X., and Hu, X. (2013). Runoff and soil erosion as affected by plastic mulch patterns in vegetable field at Dianchi lake's catchment, China. Agricultural water management 122, 20-27.

Zhang, H., Miles, C., Ghimire, S., Benedict, C., Zasada, I., and DeVetter, L. (2019). Polyethylene and biodegradable plastic mulches improve growth, yield, and weed management in floricane red raspberry. Scientia Horticulturae 250, 371-379.

Zhang, M., Bi, J., Chen, W., Zhang, X., and Lu, J. (2018). Evaluation of calculation models for the thermal conductivity of soils. International Communications in Heat and Mass Transfer 94, 14-23.

Zhang, S., Lövdahl, L., Grip, H., Tong, Y., Yang, X., and Wang, Q. (2009). Effects of mulching and catch cropping on soil temperature, soil moisture and wheat yield on the Loess Plateau of China. Soil and Tillage Research102, 78-86.

Zhao, Y., Zhai, X., Wang, Z., Li, H., Jiang, R., Lee Hill, R., Si, B., and Hao, F. (2018). Simulation of soil water and heat flow in ridge cultivation with plastic film mulching system on the Chinese Loess Plateau. Agricultural Water Management 202, 99-112.

Zhou, L., Feng, H., Zhao, Y., Qi, Z., Zhang, T., He, J., and Dyck, M. (2017). Drip irrigation lateral spacing and mulching affects the wetting pattern, shoot-root regulation, and yield of maize in a sandlayered soil. Agricultural water management 184, 114-123.

Zribi, W., Aragüés, R., Medina, E., and Faci, J. (2015). Efficiency of inorganic and organic mulching materials for soil evaporation control. Soil and Tillage Research 148, 40-45. 
Table 1. The impact of tillage systems combined with soil solarisation technology on soil thermal-physical properties

\begin{tabular}{|c|c|c|c|c|}
\hline \multicolumn{2}{|c|}{$\begin{array}{l}\text { Soil thermal-physical } \\
\text { properties }\end{array}$} & \multirow{2}{*}{$\begin{array}{l}\text { Main effect } \\
\text { Tillage systems } \\
\text { decrease soil } \\
\rho_{b} \text {. }\end{array}$} & \multirow{2}{*}{$\begin{array}{l}\text { Reasons } \\
\text { Ploughing process followed by harrowing reduces soil compaction and } \\
\text { plays an important role in reducing soil } \rho_{b} \text {. }\end{array}$} & \multirow{2}{*}{$\begin{array}{l}\text { References } \\
\text { (Downie et al., 2015; } \\
\text { Dunbabin et al., 2013; Muñoz- } \\
\text { Romero et al., 2010) }\end{array}$} \\
\hline \multirow{3}{*}{ Physical } & $\begin{array}{l}\text { Soil bulk density } \\
\left(\rho_{b}\right)\end{array}$ & & & \\
\hline & Soil porosity $(\Phi)$ & $\begin{array}{l}\text { Tillage systems } \\
\text { increase soil } \Phi \text {. }\end{array}$ & Tillage reduces soil $\rho_{b}$ resulting in an increase in $\Phi$. & $\begin{array}{l}\text { (Figueiredo et al., 2017; Głąb } \\
\text { and Kulig, 2008) }\end{array}$ \\
\hline & $\begin{array}{l}\text { Soil volumetric } \\
\text { moisture content } \\
(\theta)\end{array}$ & $\begin{array}{l}\text { Tillage systems } \\
\text { increase } \theta \text {. }\end{array}$ & $\begin{array}{l}\text { Soil } \theta \text { is directly proportional to moisture content. Tillage increases stored } \\
\text { water by increasing infiltration and reducing evaporation. }\end{array}$ & $\begin{array}{l}\text { (Copec et al., 2015; Kuzucu } \\
\text { and Dökmen, 2015) }\end{array}$ \\
\hline \multirow{5}{*}{ Thermal } & $\begin{array}{l}\text { Soil thermal } \\
\text { conductivity }(k)\end{array}$ & $\begin{array}{l}\text { Soil } k \\
\text { decreases with } \\
\text { tillage. }\end{array}$ & $\begin{array}{l}\text { Soil } k \text { is directly proportional to soil } \rho_{b} \text {, tillage reduces } \rho_{b} \text { and the } \\
\text { disturbance of soil by tillage can change the air to soil particle volume by } \\
\text { creating additional air pockets that may be responsible for reducing the } \\
\text { heat capacity of the tilled zone, decreasing soil } k \text {. }\end{array}$ & $\begin{array}{l}\text { (Allmar et al., 2000; Blanco- } \\
\text { Canqui and Ruis 2018; Dec et } \\
\text { al., 2009; Usowicz et al., 2017) }\end{array}$ \\
\hline & $\begin{array}{l}\text { Soil thermal flux } \\
\text { density }(q h)\end{array}$ & $\begin{array}{l}\text { Soil } q h \\
\text { decreases with } \\
\text { tillage. }\end{array}$ & $\begin{array}{l}\text { Soil } q h \text { is directly proportional to soil } k \text {, tillage decreases soil } k \text { by } \\
\text { reducing } \rho_{b} \text { and increasing } \Phi \text {, resulting in a decrease in soil } q h \text {. }\end{array}$ & $\begin{array}{l}\text { (Al-Shammary et al., 2017; } \\
\text { Azooz et al., 1997; Dec et al., } \\
\text { 2009) }\end{array}$ \\
\hline & $\begin{array}{l}\text { Soil volumetric } \\
\text { heat capacity } \\
\left(C_{v}\right)\end{array}$ & $\begin{array}{l}\text { Soil } C_{v} \\
\text { decreases with } \\
\text { soil tillage. }\end{array}$ & Soil $C_{v}$ is directly proportional to soil $\rho_{b}$, tillage reduces soil $\rho_{b}$. & $\begin{array}{l}\text { (Blanco-Canqui and Ruis, } \\
\text { 2018; Evett, et al., 2012; } \\
\text { Usowicz et al., 2017) }\end{array}$ \\
\hline & $\begin{array}{l}\text { Soil thermal } \\
\text { diffusivity } \\
\text { (D) }\end{array}$ & $\begin{array}{l}\text { Soil } D \\
\text { decreases with } \\
\text { tillage. }\end{array}$ & $\begin{array}{l}\text { Soil } D \text { is dependent on soil } \rho_{b}, \theta \text { and } \Phi \text {, a decrease in } \rho_{b} \text { and increase in } \Theta \\
\text { result in a significant decrease in soil } k \text { and } C_{v} \text {, decreasing } D \text {. }\end{array}$ & (Blanco-Canqui \& Ruis, 2018) \\
\hline & $\begin{array}{l}\text { Soil temperature } \\
\left(T_{s}\right)\end{array}$ & $\begin{array}{l}\text { The } T_{s} \\
\text { increases with } \\
\text { tillage. }\end{array}$ & $\begin{array}{l}\text { Tillage helps to loosen soil and increase gas exchange between the soil } \\
\text { pores and the environment, increasing } T_{s} \text {. }\end{array}$ & \\
\hline
\end{tabular}


Table 2. Modelled impacts of soil mulching systems with solarisation application on soil thermal-physical properties.

\begin{tabular}{|c|c|c|c|c|}
\hline \multicolumn{2}{|c|}{ Soil properties } & Main effect & Reasons & References \\
\hline \multirow{3}{*}{ Physical } & $\begin{array}{l}\text { Soil bulk } \\
\text { density }\left(\rho_{b}\right)\end{array}$ & $\begin{array}{l}\text { Soil mulching } \\
\text { improves/decreases } \\
\text { soil } \rho_{b} \text {. }\end{array}$ & $\begin{array}{l}\text { Soil mulching reduces soil compaction by decreasing soil moisture } \\
\text { evaporation, thereby helping to improve soil quality and reducing soil } \rho_{b} \\
\text { compared to uncovered soil. Also, surface covering by plastic mulch } \\
\text { prevents mechanical perturbations in the topsoil which can affect soil } \rho_{b} \text {. } \\
\text { Soil organic matter with solarisation application increases soil elasticity } \\
\text { which leads to reduction in soil compaction, resulting in reduced soil } \rho_{b} \text {. }\end{array}$ & $\begin{array}{l}\text { (Al-Shammary and Al- } \\
\text { Sadoon, 2014; } \\
\text { Subrahmaniyan et al. 2006) }\end{array}$ \\
\hline & $\begin{array}{l}\text { Soil porosity } \\
(\Phi)\end{array}$ & $\begin{array}{l}\text { Increasing mulch } \\
\text { application and } \\
\text { mulch properties } \\
\text { increase soil } \Phi .\end{array}$ & $\begin{array}{l}\text { Soil } \rho_{b} \text { is decreased by reducing soil compaction with soil mulching, } \\
\text { compared to no mulch, thus increasing soil } \Phi \text { with soil mulching. }\end{array}$ & $\begin{array}{l}\text { (Kader et al., 2017; } \\
\text { Nishigaki et al., 2017; } \\
\text { Nzeyimana et al., 2017) }\end{array}$ \\
\hline & $\begin{array}{l}\text { Soil volumetric } \\
\text { moisture } \\
\text { content } \\
(\theta)\end{array}$ & $\begin{array}{l}\text { Mulching system } \\
\text { properties increase } \\
\text { soil } \theta \text {. }\end{array}$ & $\begin{array}{l}\text { Soil mulching reduces soil water evaporation and helps retain soil moisture } \\
\text { content }(\mu) \text {, which is an effective way to reduce soil irrigation } \\
\text { consumption. Also, increased soil } \Phi \text { in mulch treated soil increases soil } \\
\text { hydraulic conductivity and, and thus increases in soil } \theta \text {. }\end{array}$ & $\begin{array}{l}\text { (Adekiya et al., 2017; Al- } \\
\text { Shammary et al., 2016; Liu } \\
\text { et al., 2018) }\end{array}$ \\
\hline \multirow{5}{*}{ Thermal } & $\begin{array}{l}\text { Soil thermal } \\
\text { conductivity } \\
(k)\end{array}$ & $\begin{array}{l}k \text { of the soil } \\
\text { increases when } \\
\text { mulch application is } \\
\text { increased. }\end{array}$ & $\begin{array}{l}\text { Soil } k \text { is directly proportional to soil } \theta \text {. Soil mulching increases soil } \theta \text { by } \\
\text { decreasing water lost through evaporation, consequently increasing soil } k \\
\text { when compared to soil without mulch. }\end{array}$ & $\begin{array}{l}\text { (Al-Shammary and Al- } \\
\text { Sadoon, 2014; Anikwe et } \\
\text { al., 2007; Azooz et al., } \\
\text { 1997; Usowicz et al., 2017) }\end{array}$ \\
\hline & $\begin{array}{l}\text { Soil thermal } \\
\text { flux density } \\
(q h)\end{array}$ & $\begin{array}{l}\text { Soil } q h \text { increases } \\
\text { with mulching. }\end{array}$ & $\begin{array}{l}\text { Soil } q h \text { is directly proportional to soil } k \text { and heat } *\left(\frac{d t}{d x}\right) \text {. Soil } k \text { increases } \\
\text { with mulching, and with the increase in temperature by mulching, a } \\
\text { relatively large net radiation occur at the soil surface. Water condenses } \\
\text { under the mulch during the night, and reflected radiation is absorbed from } \\
\text { the soil which maintains } T_{s} \text {, thus increasing soil } q h \text {. }\end{array}$ & $\begin{array}{l}\text { (Al-Shammary and Al- } \\
\text { Sadoon, 2014; Ham et al. } \\
\text { 1993) }\end{array}$ \\
\hline & $\begin{array}{l}\text { Soil } \\
\text { volumetric } \\
\text { heat capacity } \\
\left(C_{v}\right)\end{array}$ & $\begin{array}{l}\text { Soil } C_{v} \text { increases } \\
\text { with mulching. }\end{array}$ & $\begin{array}{l}\text { Soil } C_{v} \text { increases as } \theta \text { increases. The soil mulching helps the soil's water- } \\
\text { holding capacity compared to soil without mulching. The increase in soil } \mu \\
\text { increases the heat storage capacity of the soil. }\end{array}$ & $\begin{array}{l}\text { (Al-Shammary and Al- } \\
\text { Sadoon, 2014) }\end{array}$ \\
\hline & $\begin{array}{l}\text { Soil thermal } \\
\text { diffusivity } \\
(D)\end{array}$ & $\begin{array}{l}\text { Soil } \mathcal{D} \text { decreases } \\
\text { with mulching. }\end{array}$ & $\begin{array}{l}\text { Soil covering reduces soil compaction which results in a decrease in } \rho_{b} \\
\text { which directly affects soil } k \text { and } C_{v} \text {, and indirectly affects soil } D \text {, } \\
\text { consequently reducing soil } D \text { compared to soil without covering. }\end{array}$ & (Tong et al., 2017) \\
\hline & $\begin{array}{l}\text { Soil } \\
\text { temperature } \\
\left(T_{S}\right)\end{array}$ & $\begin{array}{l}T_{s} \text { increases with } \\
\text { mulching. }\end{array}$ & $\begin{array}{l}\text { Solar radiation passes through the mulch and heats the air and soil beneath } \\
\text { the mulch and the heat is trapped by the solarisation system, reducing the } \\
\text { soil thermal loss which increases } T_{s}\end{array}$ & \\
\hline
\end{tabular}

$* d t$ is the difference in soil temperature between two depths, and $d x$ is the vertical distance between the depths (m). 
Table 3. Modelled impacts of fertiliser with solarisation application on soil thermal-physical properties.

\begin{tabular}{|c|c|c|c|c|}
\hline \multicolumn{2}{|c|}{ Soil properties } & \multirow{2}{*}{$\begin{array}{l}\text { Main effect } \\
\text { Fertiliser } \\
\text { decreases soil } \rho_{b} \text {. }\end{array}$} & \multirow{2}{*}{$\begin{array}{l}\text { Reasons } \\
\text { Fertiliser decreases structural stability by increasing organic } \\
\text { content with a denser mineral fraction of the soil, which can } \\
\text { decrease soil } \rho_{b} \text {. }\end{array}$} & \multirow{4}{*}{$\begin{array}{l}\text { References } \\
\text { (Chaudhari et al., 2013; Guo et } \\
\text { al., 2016; Haynes and Naidu, } \\
\text { 1998) } \\
\text { (Al-Shammary et al., 2017; } \\
\text { Haynes and Naidu, 1998; Li et al., } \\
\text { 2017) } \\
\text { ( Gao et al., 2018; Haynes and } \\
\text { Naidu, 1998;) }\end{array}$} \\
\hline \multirow{3}{*}{ Physical } & Soil bulk density $\left(\rho_{b}\right)$ & & & \\
\hline & Soil porosity $(\Phi)$ & $\begin{array}{l}\text { Fertiliser } \\
\text { increases soil } \Phi \text {. }\end{array}$ & $\begin{array}{l}\text { Decreasing soil } \rho_{b} \text { increases total pore space by increasing organic } \\
\text { content. }\end{array}$ & \\
\hline & $\begin{array}{l}\text { Soil volumetric } \\
\text { moisture content }(\theta)\end{array}$ & $\begin{array}{l}\text { Fertiliser } \\
\text { increases soil } \theta \text {. }\end{array}$ & $\begin{array}{l}\text { Addition of fertiliser increases the water-holding capacity of the } \\
\text { soil by increasing the organic matter content and } \theta \text {. }\end{array}$ & \\
\hline \multirow{4}{*}{ Thermal } & $\begin{array}{l}\text { Soil thermal } \\
\text { conductivity }(k)\end{array}$ & $\begin{array}{l}\text { Soil } k \text { increases } \\
\text { with fertiliser use }\end{array}$ & $\begin{array}{l}\text { Soil } k \text { is dependent on soil } \Phi \text {, fertiliser increases } \Phi \text { by increasing } \\
\text { the organic matter content of the soil, increasing soil } k \text {. }\end{array}$ & $\begin{array}{l}\text { (Jia et al., 2019; Liu et al., 2018; } \\
\text { Usowicz et al., 2017) }\end{array}$ \\
\hline & $\begin{array}{l}\text { Soil thermal flux } \\
\text { density }(q h)\end{array}$ & $\begin{array}{l}\text { Soil } q h \text { increases } \\
\text { with fertiliser use }\end{array}$ & $\begin{array}{l}\text { Fertiliser increases the organic matter in the soil, influencing soil } \\
k \text { and heat production by increasing the water-holding capacity of } \\
\text { the soil and increasing heat transfer, influencing soil } q h \text {. }\end{array}$ & \multirow[t]{2}{*}{ (Al-Shammary et al., 2017) } \\
\hline & $\begin{array}{l}\text { Soil volumetric heat } \\
\text { capacity }\left(C_{v}\right)\end{array}$ & $\begin{array}{l}\text { Soil } C_{v} \text { is } \\
\text { influenced by } \\
\text { fertiliser use }\end{array}$ & $\begin{array}{l}\text { Soil } C_{v} \text { is dependent on soil } \rho_{b} \text { and } \theta \text {. Fertilisers decrease soil } \rho_{b} \text {, } \\
\text { increase } \theta \text { by increasing the organic matter content in the soil, } \\
\text { impacting soil } C_{v} \text {. }\end{array}$ & \\
\hline & $\begin{array}{l}\text { Soil thermal } \\
\text { diffusivity }(D)\end{array}$ & $\begin{array}{l}\text { Soil } \mathcal{D} \text { increases } \\
\text { with fertiliser use }\end{array}$ & $\begin{array}{l}\text { Increasing the organic matter significantly affects both } K \text { and } C_{v} \\
\text { through soil } \rho_{b} \text { and } \theta \text { changes, which increase } \mathcal{D} \text {. }\end{array}$ & $\begin{array}{l}\text { (Al-Shammary and Al-Sadoon, } \\
\text { 2014; Dec et al., 2009) }\end{array}$ \\
\hline
\end{tabular}


Table 4. Modelled impacts of moisture content $(\mu)$ with solarisation application on soil thermal-physical properties.

\begin{tabular}{|c|c|c|c|c|}
\hline \multicolumn{2}{|c|}{ Soil properties } & Main effect & Reasons & References \\
\hline \multirow[t]{2}{*}{ Physical } & $\begin{array}{l}\text { Soil bulk density } \\
\left(\rho_{b}\right) \\
\text { Soil porosity }(\Phi)\end{array}$ & $\begin{array}{l}\text { Soil } \rho_{b} \text { decreases with } \\
\mu \text { increase. } \\
\text { Soil } \Phi \text { increases with } \\
\text { moisture content } \\
\text { increase. }\end{array}$ & $\begin{array}{l}\text { Soil } \rho_{b} \text { affects soil compression behaviour changes, which } \\
\text { affects soil } \rho_{b} \text {. } \\
\text { The soil } \Phi \text { has an inverse relationship with } \rho_{b} \text { which decreases } \\
\text { with increasing soil } \mu \text {, and with more pore space in the soil, } \\
\text { soil } \rho_{b} \text { decreases and soil } \Phi \text { increases. }\end{array}$ & (Al-Shammary et al., 2017) \\
\hline & $\begin{array}{l}\text { Soil volumetric } \\
\text { moisture content } \\
(\theta)\end{array}$ & $\begin{array}{l}\text { Soil } \theta \text { increases with } \\
\text { moisture content. }\end{array}$ & Soil $\theta$ is directly proportional to soil $\mu$. & (Al-Shammary et al., 2017) \\
\hline \multirow{4}{*}{ Thermal } & $\begin{array}{l}\text { Soil thermal } \\
\text { conductivity }(k)\end{array}$ & $\begin{array}{l}\text { Soil } \mathrm{k} \text { increases with } \\
\text { increasing soil } \mu \text {. }\end{array}$ & $\begin{array}{l}\text { The } k \text { of soil has an increasing logarithmic relationship with } \\
\text { soil } \mu \text {, consequently improving the heat flow and enhancing } \\
\text { soil } k \text {. }\end{array}$ & $\begin{array}{l}\text { (Abu-Hamdeh and Reeder, } \\
\text { 2000; Łydżba et al., 2016; } \\
\text { Usowicz et al., 2017) }\end{array}$ \\
\hline & $\begin{array}{l}\text { Soil thermal flux } \\
\text { density }(q h)\end{array}$ & $\begin{array}{l}\text { Soil } q h \text { has a positive } \\
\text { correlation with soil } \mu \text {. }\end{array}$ & $\begin{array}{l}\text { The } q h \text { is directly proportional to soil } k \text { and depth. When the } \\
\text { soil } \mu \text { increases, } k \text { also increases. Also, soil } q h \text { has a } \\
\text { relationship to soil depth which influences } \mu \text {. }\end{array}$ & (Nishigaki et al., 2017) \\
\hline & $\begin{array}{l}\text { Soil volumetric heat } \\
\text { capacity }\left(C_{v}\right)\end{array}$ & $\begin{array}{l}\text { Soil } C_{v} \text { increases with } \\
\text { soil } \mu \text {. }\end{array}$ & $\begin{array}{l}\text { Soil } C_{v} \text { increases linearly with } \mu \text {, solar radiation absorption by } \\
\text { soil increases with increased soil } \mu \text {, increasing soil } C_{v} \text {. }\end{array}$ & $\begin{array}{l}\text { (Al-Kayssi et al., 1990; Liu et } \\
\text { al., 2008) }\end{array}$ \\
\hline & $\begin{array}{l}\text { Soil thermal } \\
\text { diffusivity } \\
\text { (D) }\end{array}$ & $\begin{array}{l}\text { Soil } D \text { increases with } \\
\mu \text {. }\end{array}$ & $\begin{array}{l}\text { Soil } \mu \text { improves the thermal transfer between soil particles and } \\
\text { air. Furthermore, } D \text { is directly proportional to soil } k \text {.Therefore, } \\
D \text { increases linearly with increasing } \mu \text {. }\end{array}$ & $\begin{array}{l}\text { (Miyajima et al., 2015; Usowicz } \\
\text { et al., 2016) }\end{array}$ \\
\hline
\end{tabular}


Table 5. Impacts of solarisation induced temperature $\left(T_{s}\right)$ on soil thermal-physical properties.

\begin{tabular}{|c|c|c|c|c|}
\hline \multicolumn{2}{|c|}{ Soil properties } & \multirow{3}{*}{$\begin{array}{l}\text { Main effect } \\
\text { Soil } \rho b \text { decreases with } \\
\text { increasing soil } \\
\text { temperature }\left(T_{s}\right) \text {. } \\
\text { Soil } \Phi \text { increases with } \\
\text { increasing soil } \\
\text { temperature. }\end{array}$} & \multirow{2}{*}{$\begin{array}{l}\text { Reasons } \\
T_{s} \text { changes the internal microstructure, increases decomposition of } \\
\text { organic matter, agrochemicals and biology of the soil, decreasing } \rho b \\
\text { significantly. }\end{array}$} & \multirow{2}{*}{$\begin{array}{l}\text { References } \\
\text { (Al-Shammary and Al- } \\
\text { Sadoon, 2014; van Lier } \\
\text { and Durigon, 2013) }\end{array}$} \\
\hline \multirow{3}{*}{ Physical } & $\begin{array}{l}\text { Soil bulk density } \\
\left(\rho_{b}\right)\end{array}$ & & & \\
\hline & Soil porosity $(\Phi)$ & & $\begin{array}{l}\text { Decreasing soil } \rho_{b} \text { increases air quantity in the pores and cracks, } \\
\text { increasing soil } \Phi \text {. }\end{array}$ & (Sun et al., 2016) \\
\hline & $\begin{array}{l}\text { Soil volumetric } \\
\text { moisture content } \\
(\theta)\end{array}$ & $\begin{array}{l}\text { The } T_{s} \text { with mulch is } \\
\text { influenced by soil } \theta \text {. }\end{array}$ & $\begin{array}{l}\text { Covering of soil affects } \mu \text { through } T s \text { and conserves water by reducing } \\
\text { the rate of evaporation, improving } \theta \text {. }\end{array}$ & $\begin{array}{l}\text { (Al-Shammary et al., 2016; } \\
\text { Mutetwa and Mtaita, 2014) }\end{array}$ \\
\hline \multirow{4}{*}{ Thermal } & $\begin{array}{l}\text { Soil thermal } \\
\text { conductivity }(k)\end{array}$ & $\begin{array}{l}\text { Soil } k \text { increases with } \\
\text { increasing } T s \text { in most } \\
\text { soils. }\end{array}$ & $\begin{array}{l}\text { Soil } k \text { and } T_{s} \text { are linearly related under different saturation conditions. } \\
\text { Other reasons include that thermal flow in the soil causes the } \\
\text { movement of moisture, an increase in } T_{s} \text { results in a change in water } \\
\text { state, increasing } k \text {. An increase in soil particle vibration results in the } \\
\text { soil temperature and } k \text { also increasing. }\end{array}$ & $\begin{array}{l}\text { (Al-Shammary and Al- } \\
\text { Sadoon, 2014; Lamond } \\
\text { and Pielert, 2006; Usowicz } \\
\text { et al., 2017) }\end{array}$ \\
\hline & $\begin{array}{l}\text { Soil thermal flux } \\
\text { density }(q h)\end{array}$ & $\begin{array}{l}\text { Soil } q h \text { increases with } \\
\text { increasing } T_{s} \text {. }\end{array}$ & $\begin{array}{l}\text { The } q h \text { is directly proportional to } k \text {, which increases as } T_{s} \text { increases, } \\
\text { and an increase in moisture movement results in an increase in thermal } \\
\text { flow and } k \text {. In addition, soil } \rho_{b} \text { decreases as } T_{s} \text { increases, which } \\
\text { increases heat transfer and } q h \text {. }\end{array}$ & $\begin{array}{l}\text { ( van Lier and Durigon, } \\
\text { 2013) }\end{array}$ \\
\hline & $\begin{array}{l}\text { Soil volumetric heat } \\
\text { capacity }\left(C_{v}\right)\end{array}$ & $\begin{array}{l}\text { Soil } C_{v} \text { increases with } \\
\text { increasing } T_{s}\end{array}$ & $\begin{array}{l}\text { The } T_{s} \text { resulting from soil management significantly affects soil } C_{v} \text {, } \\
\text { reduces } \rho_{b} \text { and increases } \Phi \text { and } C_{v} \text {. }\end{array}$ & $\begin{array}{l}\text { (Abu-Hamdeh, 2003; } \\
\text { Mengistu et al., 2017) }\end{array}$ \\
\hline & $\begin{array}{l}\text { Soil thermal } \\
\text { diffusivity }(D)\end{array}$ & $\begin{array}{l}\text { Soil } D \text { increases with } \\
\text { increasing } T_{s}\end{array}$ & $\begin{array}{l}\text { Soil } k \text { and } C_{v} \text { increase as } T_{s} \text { increases, which is dependent on } \rho_{b} \text { and } \mu \text {, } \\
\text { and increases } D \text {. }\end{array}$ & $\begin{array}{l}\text { (Mengistu et al., 2017; Sun } \\
\text { et al., 2016) }\end{array}$ \\
\hline
\end{tabular}




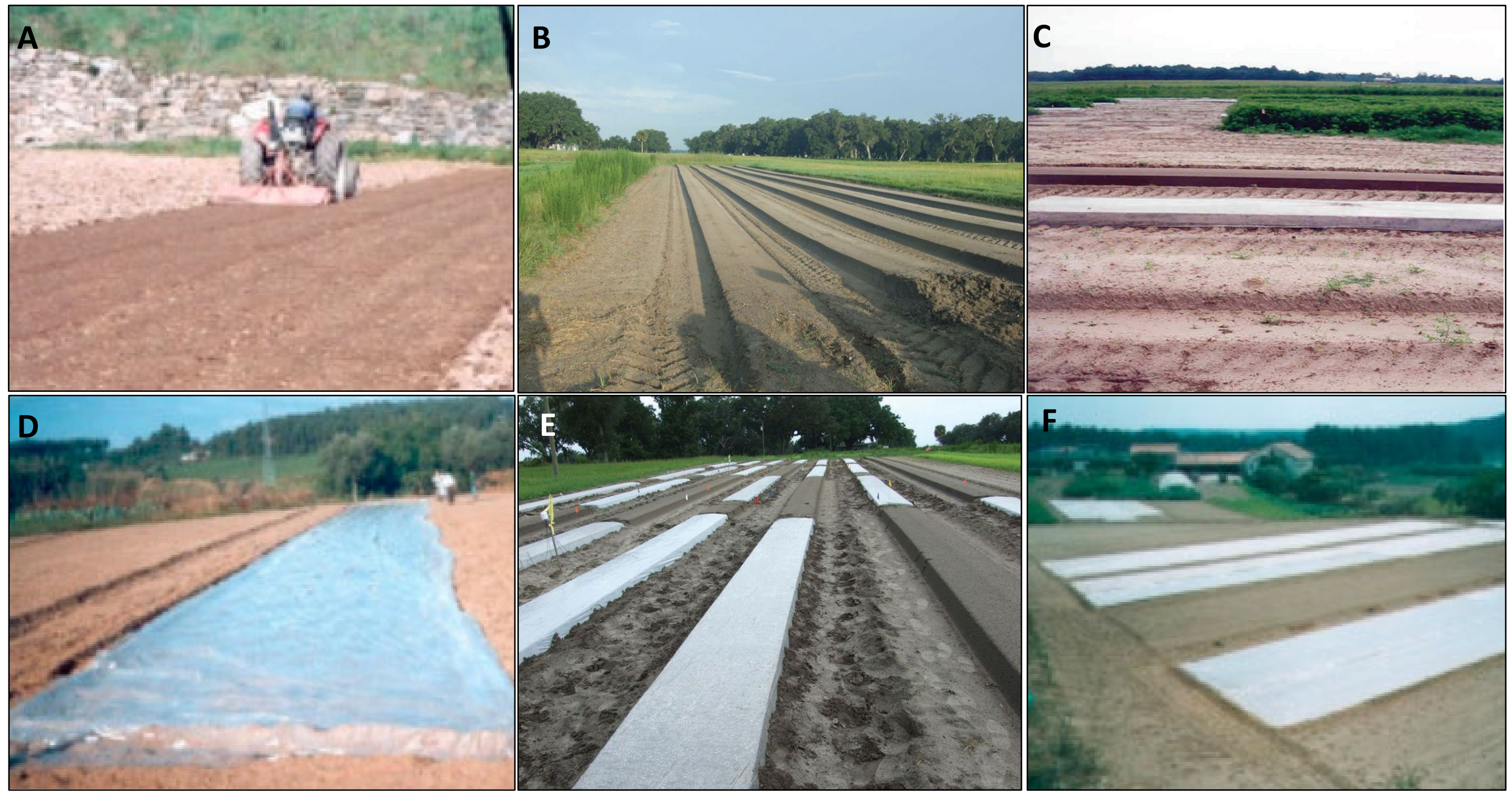

Figure 1. A: Tilled bare soil ready for solarisation; B: Soil after tillage; C: Soil preparation with fertilisers and irrigation; D: Soil covered with a polyethylene film; E and F: Placing the polyethylene film on the soil (sources: Barrera Necha and Bautista-Baños, 2016) 


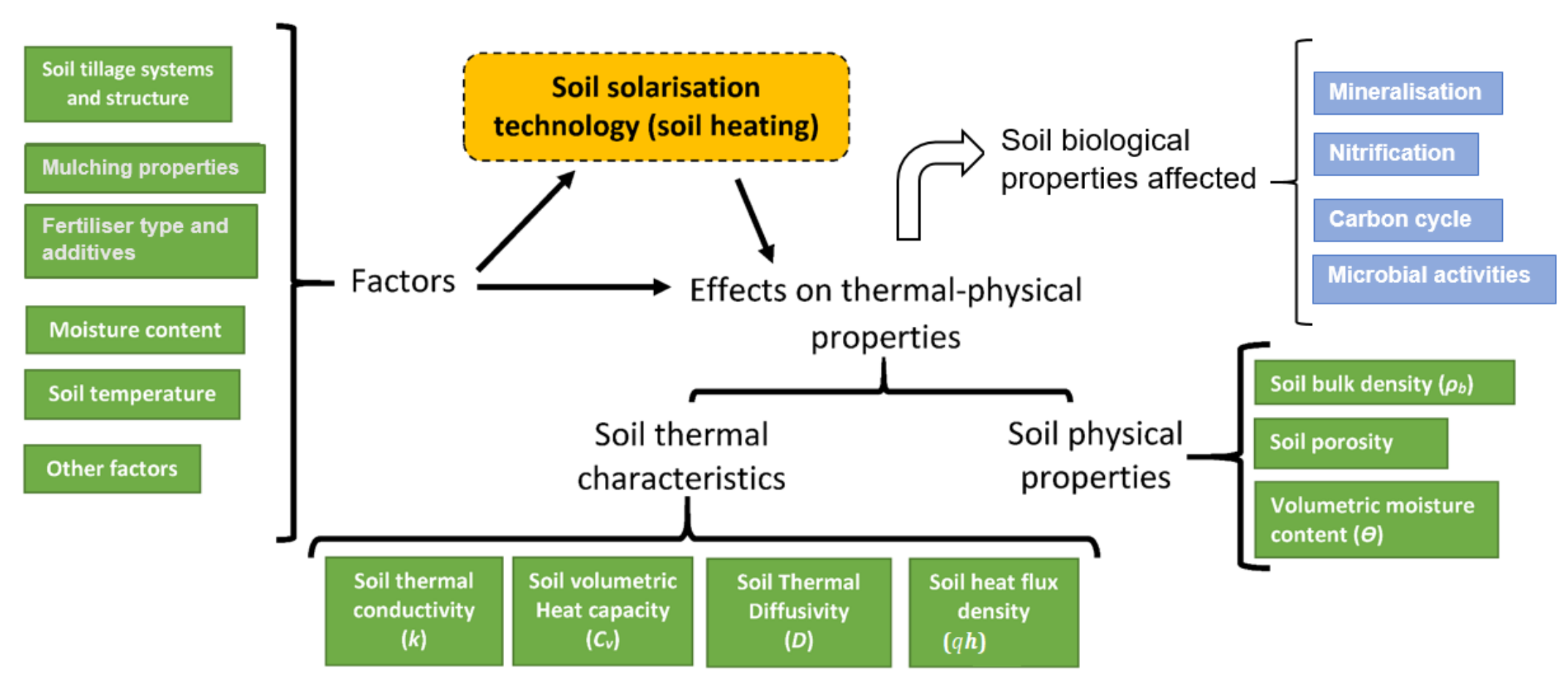

Figure 2. Basic framework of the specific factors that affect soil solarisation and soil thermal-physical properties. 


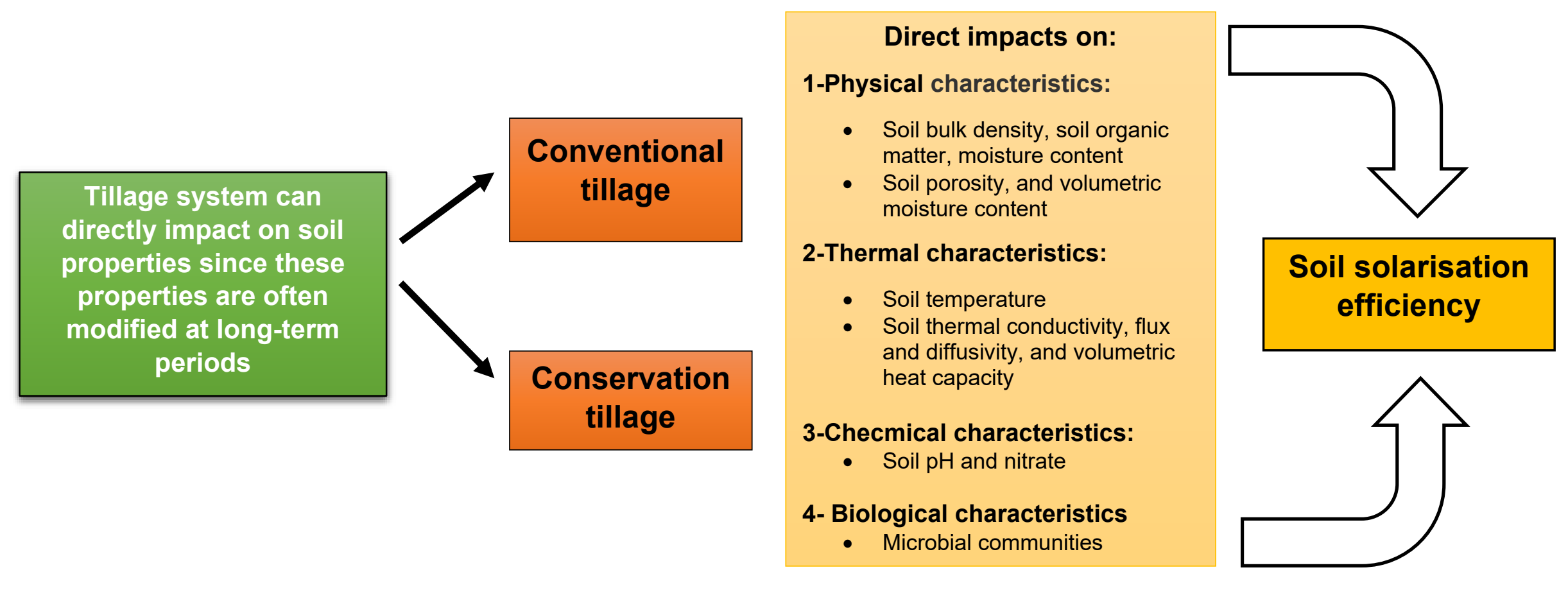

Figure 3. Schematic representation of the potential impacts of tillage system on soil physical, chemical and biological characteristics. 


\section{Mulching materials types}

Inorganic materials

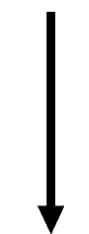

Polyethylene plastic films

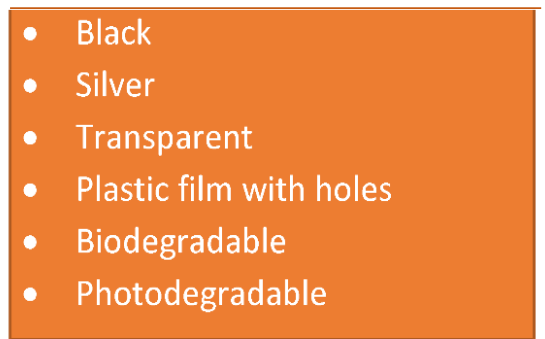

\section{Organic materials}

$\downarrow$

Plant products and animal wastes

\section{Plant:}

- Straw (rice, wheat, maize)

- Dry clips (grass, weeds, wood, bark)

- Chopped leaves, cassava bagasse

- Geo-textile materials husks (rice,

coconut, maize stalk)

- Small branches of tree paper

(newspaper, kraft paper)
Mixed materials

Special materials

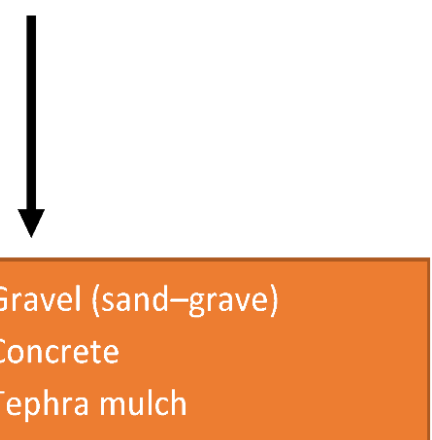

- Concrete

- Tephra mulch

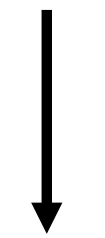

- Plastic+straw+concrete

- Plastic+straw+grass

- Plastic+straw+gravel

- Wheat straw+ black plastic

- Rice straw+ clear plastic

- Straw, plastic +geo-textiles

- Plastic

Animal wastes:

- Composed

- Cattle waste

Figure 4. Mulching materials used for solarisation technology. 


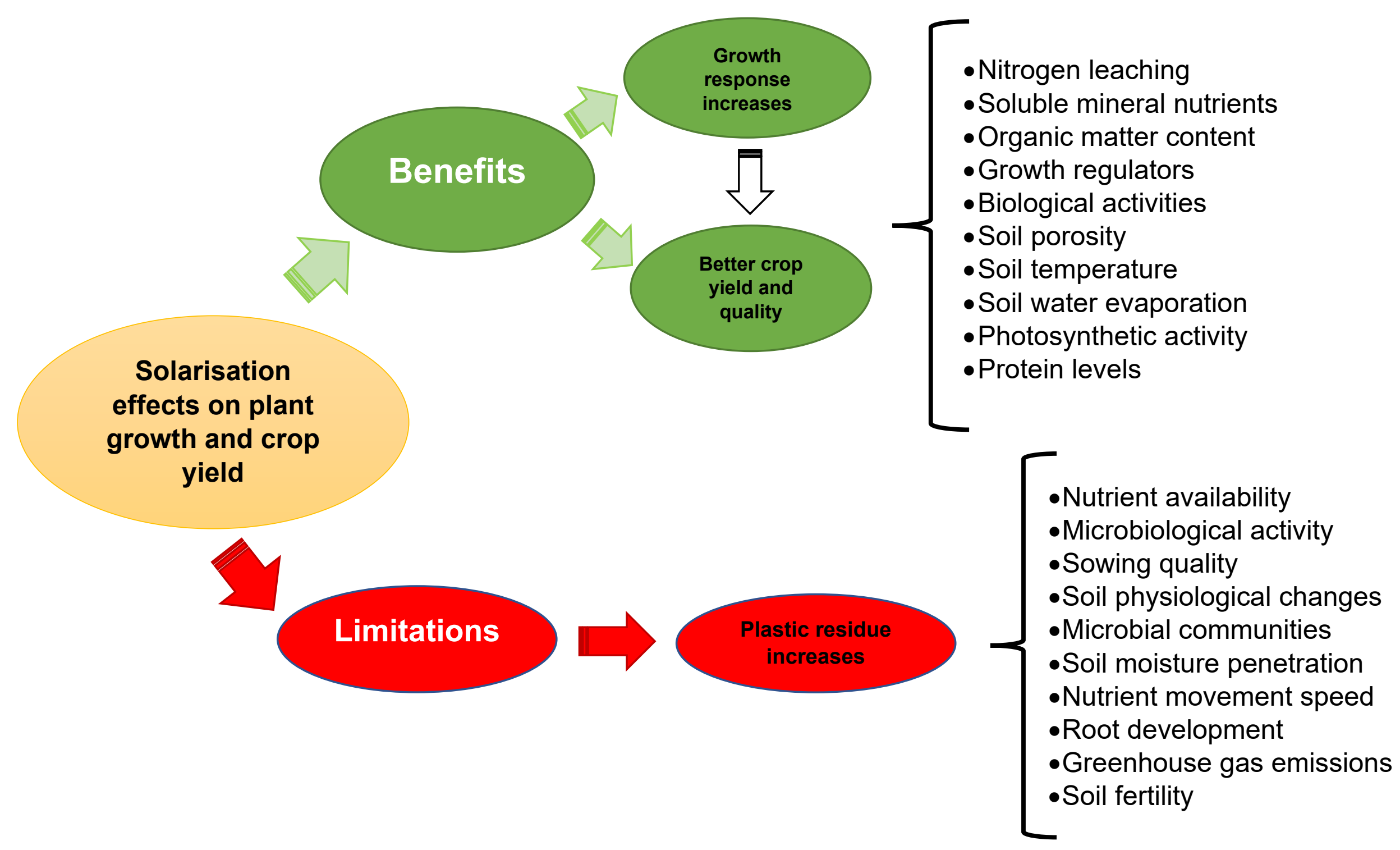

Figure 5. Solarisation effects on plant growth and crop yield 